\title{
Representation of dissolved organic carbon in the JULES land surface model (vn4.4_JULES-DOCM)
}

\author{
Mahdi Nakhavali ${ }^{1}$, Pierre Friedlingstein ${ }^{1}$, Ronny Lauerwald ${ }^{1}$, Jing Tang ${ }^{2,3}$, Sarah Chadburn ${ }^{1,4}$, \\ Marta Camino-Serrano ${ }^{5}$, Bertrand Guenet ${ }^{6}$, Anna Harper ${ }^{1}$, David Walmsley ${ }^{7}$, Matthias Peichl ${ }^{8}$, and Bert Gielen ${ }^{9}$ \\ ${ }^{1}$ College of Engineering, Mathematics, and Physical Sciences, University of Exeter, Exeter, EX4 4QE, UK \\ ${ }^{2}$ Terrestrial Ecology Section, Department of Biology, University of Copenhagen, Copenhagen, Denmark \\ ${ }^{3}$ Centre for Permafrost, University of Copenhagen, Copenhagen, Denmark \\ ${ }^{4}$ University of Leeds, School of Earth and Environment, Leeds, UK \\ ${ }^{5}$ CREAF, Barcelona, Catalonia, Spain \\ ${ }^{6}$ Laboratoire des Sciences du Climat et de l'Environnement, LSCE/IPSL, CEA-CNRS-UVSQ, Université Paris-Saclay, \\ 91191 Gif-sur-Yvette, France \\ ${ }^{7}$ Leuphana University Lüneburg, Lüneburg, Germany \\ ${ }^{8}$ Swedish University of Agricultural Sciences, Department of Forest Ecology and management, Umeå, Sweden \\ ${ }^{9}$ Department of Biology, Research Group of Plant and Vegetation Ecology, University of Antwerp, Antwerp, Belgium
}

Correspondence: Mahdi Nakhavali (m.nakhavali@exeter.ac.uk)

Received: 12 July 2017 - Discussion started: 24 July 2017

Revised: 31 October 2017 - Accepted: 3 January 2018 - Published: 12 February 2018

\begin{abstract}
Current global models of the carbon (C) cycle consider only vertical gas exchanges between terrestrial or oceanic reservoirs and the atmosphere, thus not considering the lateral transport of carbon from the continents to the oceans. Therefore, those models implicitly consider all of the $\mathrm{C}$ which is not respired to the atmosphere to be stored on land and hence overestimate the land $\mathrm{C}$ sink capability. A model that represents the whole continuum from atmosphere to land and into the ocean would provide a better understanding of the Earth's C cycle and hence more reliable historical or future projections. A first and critical step in that direction is to include processes representing the production and export of dissolved organic carbon in soils. Here we present an original representation of dissolved organic $\mathrm{C}$ (DOC) processes in the Joint UK Land Environment Simulator (JULES-DOCM) that integrates a representation of DOC production in terrestrial ecosystems based on the incomplete decomposition of organic matter, DOC decomposition within the soil column, and DOC export to the river network via leaching. The model performance is evaluated in five specific sites for which observations of soil DOC concentration are available. Results show that the model is able to reproduce the DOC concentration and controlling processes, including leaching to the
\end{abstract}

riverine system, which is fundamental for integrating terrestrial and aquatic ecosystems. Future work should include the fate of exported DOC in the river system as well as DIC and POC export from soil.

\section{Introduction}

An estimated 1.9 $\mathrm{Pg} \mathrm{Cyr}^{-1}$ is exported from soils through the river network to the oceans, which represents a significant flux in the global carbon (C) cycle (Cole et al., 2007; Regnier et al., 2013) and can affect the biological and chemical properties of both aquatic (Aitkenhead and Mcdowell, 2000) and terrestrial ecosystems (Kalbitz et al., 2000). In land surface models that are part of Earth system models, only vertical fluxes of carbon between land and atmosphere are considered, whilst lateral export fluxes are not included. This leads to an overestimation of soil organic C (SOC) sequestration and terrestrial C sinks (Janssens et al., 2003; Jackson et al., 2002). Hence we need to move towards a boundless $C$ cycle model which accounts for lateral fluxes and thus produces more accurate projections of atmospheric $\mathrm{CO}_{2}$ concentrations and C stocks (Battin et al., 2009). One of the lateral 
fluxes that has been neglected is the transfer of carbon from terrestrial to aquatic ecosystems in the form of dissolved organic C (DOC), which has been shown to be increased by anthropogenic perturbation such as land use change (like deforestation) and increased atmospheric $\mathrm{CO}_{2}$ concentrations (Regnier et al., 2013). DOC contributes about $37 \%$ of the global riverine carbon exports to the coast (Meybeck, 1993) and adds to the net heterotrophy of inland waters and related $\mathrm{CO}_{2}$ emission fluxes to the atmosphere.

The main sources of DOC in terrestrial ecosystems are plant residues (Khomutova et al., 2000) and humus and root exudates (Kalbitz et al., 2000; Van den berg et al., 2012; Marschner, 1995). DOC within the soil can be the product of in situ production or can be brought in by advective fluxes with soil water transport. It has been hypothesized that the loss of the carbon from the soil by leaching has to be taken into account to reasonably reassess the terrestrial $\mathrm{C}$ budget of Europe (Siemens, 2003). The fate of this DOC within inland water networks, i.e. the proportion transported to the coast or respired and emitted to the atmosphere, is the key to understanding the link to the other compartments of the Earth system (Cole et al., 2007; Battin et al., 2009). Nevertheless, it is a difficult task to link riverine and terrestrial fluxes by empirical methods because (1) riverine fluxes are integrating fluxes from different land use systems (Kindler et al., 2011; Boyer and Groffman, 1996) with different leaching rates and DOC quality, (2) in-stream transformation makes it difficult to trace back terrestrial DOC sources, and (3) it is difficult to separate natural and anthropogenic perturbation fluxes (Schelker et al., 2013; Regnier et al., 2013).

A physical-based modelling approach explicitly representing different terrestrial sources and processes involved in DOC cycling within the soil column and DOC leaching from the soil can help overcome these difficulties. Representation of DOC cycling within the soil column is also a major step toward simulating deep soil SOC formation (Rumpel and Kögel-Knabner, 2011). Physical-based models help us to understand the processes involved in soil DOC cycling and leaching as well as the biogeochemistry of SOC in general. So far several models have been developed that simulate DOC with different temporal and spatial resolution, from $15 \mathrm{~min}$ as in SOLVEG-II (Ota et al., 2013) to monthly as in ECOSSE (Smith et al., 2010) or RivCM (Langerwisch et al., 2016), and from the site scale as in DyDOC (Michalzik et al., 2003) to the global scale as in TEM (Kicklighter et al., 2013). Some of these models represent DOC leaching, whereas others do not. Each model has its own particular definition for carbon pools (including DOC) and DOC production processes which can be based on turnover time as in TERRAFLUX (Neff and Asner, 2001) or based on chemical composition as in the DyDOC model (Michalzik et al., 2003). Although all these models have been evaluated, with the exception of the TEM model which was tested for arctic rivers, none of them has demonstrated an ability to represent DOC production, processing, and transport on the global scale.

In general, most of the models containing decomposition are based on first-order kinetics (Olson, 1963). Frequently, models tend to represent the topsoil layer as the major source for DOC production and export (Koven et al., 2013); other studies (Rumpel and Kögel-Knabner, 2011; Braakhekke et al., 2013) highlight the importance of DOC for SOC production in deeper soil layers.

Here we present an original representation of DOC processes in the Joint UK Land Environment Simulator (JULESDOCM) that integrates a representation of DOC production in terrestrial ecosystems based on the incomplete decomposition of organic matter, DOC decomposition within the soil column, and DOC export to the river network via leaching. JULES has been used to evaluate the global C cycle (e.g. Le Quéré, et al., 2015; Sitch et al., 2015) and its role in the Earth system, but to date lacks the critical processes of DOC production and export. The aim of this study is to include a representation of DOC produced in terrestrial soils down to $3 \mathrm{~m}$ (as soil hydrology and carbon are simulated over a $3 \mathrm{~m}$ soil profile in JULES). We assume an incomplete decomposition of organic matter and its subsequent fate as DOC, including (i) DOC decomposition and release as $\mathrm{CO}_{2}$ to the atmosphere and (ii) DOC export to the riverine system via leaching, to test the new model in different ecosystems and to evaluate it against specific sites where soil DOC measurements were available. Other forms of $\mathrm{C}$ need different processes to fully represent the land-to-ocean aquatic continuum of the global C cycle. Hence future work should include DIC and POC export from soils as well as the fate of all exported carbon in the river system.

\section{Material and methods}

\subsection{JULES model}

JULES is a process-based model which represents energy, water, and $\mathrm{C}$ cycling among vegetation, soil, and atmosphere as described in Best et al. (2011) and Clark et al. (2011). Vegetation processes in JULES are represented in a dynamic vegetation model (TRIFFID) distinguishing nine plant function types (PFTs) on the global scale: tropical and temperate broadleaf evergreen trees, broadleaf deciduous trees, needleleaf evergreen trees and deciduous trees, $\mathrm{C}_{3}$ and $\mathrm{C}_{4}$ grasses, and evergreen and deciduous shrubs (Harper et al., 2016).

The representation of SOC in JULES follows the formulation of the RothC soil carbon scheme (Jenkinson et al., 1990; Jenkinson and Coleman, 2008) in distinguishing four carbon pools: decomposable plant material (DPM), resistant plant material (RPM), heterotrophic microbial biomass (BIO), and long-lived humified material (HUM). DPM and RPM pools receive litter inputs directly from the vegetation due to defoliation, mortality and disturbance, the allocation to DPM 
or RPM depending on the PFT characteristics with a higher fraction of decomposable litter provided from grasses, and a higher fraction of resistant litter provided from trees (Clark et al., 2011). HUM and BIO each receive inputs from the other two soil carbon pools as a fraction of the decomposition that is not respired to the atmosphere.

\subsection{JULES-DOCM model new features}

JULES-DOCM is an extension of JULES based on version 4.4 (vn4.4 documentation in http://jules-lsm.github.io/vn4. 4), which explicitly represents DOC cycling in soils and considers DOC leaching from the soil profile. The following section deals with the representation of DOC fluxes and processes in more details.

\subsubsection{Soil carbon profile}

SOC is specified as the main source of DOC in JULESDOCM. In JULES v4.4, each of the four SOC pools is treated as a single box down to $3 \mathrm{~m}$, without any representation of its vertical distribution. This absence of vertical distribution has consequences in terms of simulating DOC fluxes, but also potential impacts on soil $\mathrm{CO}_{2}$ fluxes considering vertical variations in soil temperature and moisture. In JULESDOCM, we introduce a vertical distribution of SOC for each soil carbon pool assuming an exponential decay with depth, with a weighting factor $\beta_{0}$ :

$\beta_{0_{i}}=e^{-\frac{z_{i}}{z_{0}}} \cdot \mathrm{dz} z_{i}$

Here, $z_{0}$ is the $e$-folding depth of C content within $1 \mathrm{~m}$ of soil (i.e. depth at which SOC decreases by a factor of $e$ relative to the surface), $z_{i}$ is the soil depth of layer $i$, and $\mathrm{dz}_{i}$ is the thickness of the soil layer. In order to estimate $z_{0}$, we used the soil data from Jobbágy and Jackson (2000) that provide the vertical distribution of SOC within a $3 \mathrm{~m}$ soil profile based on the observed soil carbon profiles across several biomes. Jobbágy and Jackson (2000) provide soil C content in the first metre $(0-1 \mathrm{~m})$ and for the first $3 \mathrm{~m}(0-3 \mathrm{~m})$, allowing us to estimate the fraction in the first metre and derive $z_{0}$ accordingly:

$\int_{0}^{1} e^{-\frac{z}{z_{0}}} d_{z}=x \int_{0}^{3} e^{-\frac{z}{z_{0}}} d_{z}$

where $x$ is the ratio of SOC content within the first $1 \mathrm{~m}$ of soil relative to the $3 \mathrm{~m}$ profile for different biomes as given by Jobbágy and Jackson (in their Table 3; Jobbágy and Jackson, 2000). Jobbágy and Jackson provide data for 11 PFTs. Here we first estimate $z_{0}$ for each of those PFTs, then regroup them into the nine JULES PFTs (see Tables S1 and S2 in the Supplement).

In order to calculate the fraction of SOC that is used as input for DOC production in each layer of the DOC model (see Eq. 4 below), the weighting factors are normalized $\left(\beta_{z_{i}}\right)$ :

$\beta_{z_{i}}=\frac{\beta_{0_{i}}}{\sum_{i=1}^{i=4} \beta_{0_{i}}}$.

\subsubsection{DOC fluxes and processes}

In JULES-DOCM, four new DOC carbon pools have been added. First the model accounts for a labile and a recalcitrant DOC pool based on their decomposition rate (Aguilar and Thibodeaux, 2005; Thibodeaux and Aguilar, 2005). The labile pool is readily available for decomposition in soil solution at all times and the recalcitrant pool is subject to a slower decomposition rate (Smith et al., 2010). DOC produced from plant material pools (DPM and RPM) and microbial biomass (BIO) is directed to the labile pool, while DOC from humus (HUM) is directed to the recalcitrant pool. Second, both the labile and the recalcitrant DOC pools have a dissolved and an adsorbed form, with only the dissolved pool being subjected to decomposition and leaching.

DOC production $\left(F_{\mathrm{P}}\right)$ follows first-order kinetics (Olson, 1963 ) and the flux of carbon from SOC to DOC pools ( $k$ for labile or recalcitrant) in each soil layer $(i)$ in $\mathrm{kg} \mathrm{C} \mathrm{m}^{-2}$ day $^{-1}$ $\left(F_{\mathrm{P}}\right.$; arrows a-d in Fig. 1$)$ is calculated as

$$
\begin{aligned}
F_{\mathrm{P}_{k, i}} & =\beta_{z_{i}} \cdot S_{\mathrm{C}_{k}} \cdot\left(1-e^{\left(-K_{\mathrm{P}} \cdot F_{\mathrm{S}}(S)_{i} \cdot F_{\mathrm{T}}\left(T_{\mathrm{Soil}}\right)_{i} \cdot F_{\mathrm{v}}(v) \cdot D_{\mathrm{f}}\right)}\right) \\
& \cdot e^{-\tau_{z_{i}}}
\end{aligned}
$$

where $S_{\mathrm{C}_{k}}$ is the amount of carbon in the soil organic pool (DPM, RPM, and BIO for DOC labile pool and HUM for recalcitrant pool) in $\mathrm{kg} \mathrm{C} \mathrm{m}^{-2}$ in whole soil, $K_{\mathrm{P}}$ is the DOC production rate in day ${ }^{-1}, F_{\mathrm{S}}(s)_{i}$ and $F_{\mathrm{T}}\left(T_{\text {soil }}\right)_{i}$ are respectively the rate modifiers due to moisture and temperature, which are controlling decomposition in each soil layer $(i)$, and $F_{\mathrm{V}}(v)$ is the fraction of the vegetation. All units are given in Table 2. The moisture and temperature rate modifiers are based on the RothC formulations (Coleman and Jenkinson, $2014) ; \tau_{z}$ is the empirical factor for a decrease in C decomposition rates with soil depth, as recently introduced in JULES (Burke et al., 2017).

The DOC production rate is further modified by $D_{\mathrm{f}}$, which considers the decrease in the SOC decomposition rate as an increase in silt plus clay content given in a fraction (Parton et al., 1987):

$D_{\mathrm{f}}=1-(0.75 \cdot($ clay + silt $))$.

After decomposition, carbon pools $\left(S_{\mathrm{C}}\right)$ are updated by the changes in each time step (daily) as follows:

$$
\begin{aligned}
& \frac{\Delta S_{\mathrm{C}_{\mathrm{DPM}}}}{\Delta t}=f_{\mathrm{DPM}} \Lambda_{\mathrm{c}}-\mathrm{R}_{\mathrm{DPM}} \sum_{i=1}^{i=4} \mathrm{~F}_{\mathrm{P}_{\mathrm{DPM}_{i}},} \\
& \frac{\Delta S_{\mathrm{C}_{\mathrm{RPM}}}}{\Delta t}=\left(1-f_{\mathrm{DPM}}\right) \Lambda_{\mathrm{c}}-R_{\mathrm{RPM}}-\sum_{i=1}^{i=4} F_{\mathrm{P}_{\mathrm{RPM}_{i}},}, \\
& \frac{\Delta S_{\mathrm{C}_{\mathrm{BIO}}}}{\Delta t}=0.46\left(1-B_{\mathrm{R}}\right) R_{\mathrm{S}}-R_{\mathrm{BIO}}-\sum_{i=1}^{i=4} F_{\mathrm{P}_{\mathrm{BIO}_{i}}}
\end{aligned}
$$

Geosci. Model Dev., 11, 593-609, 2018 


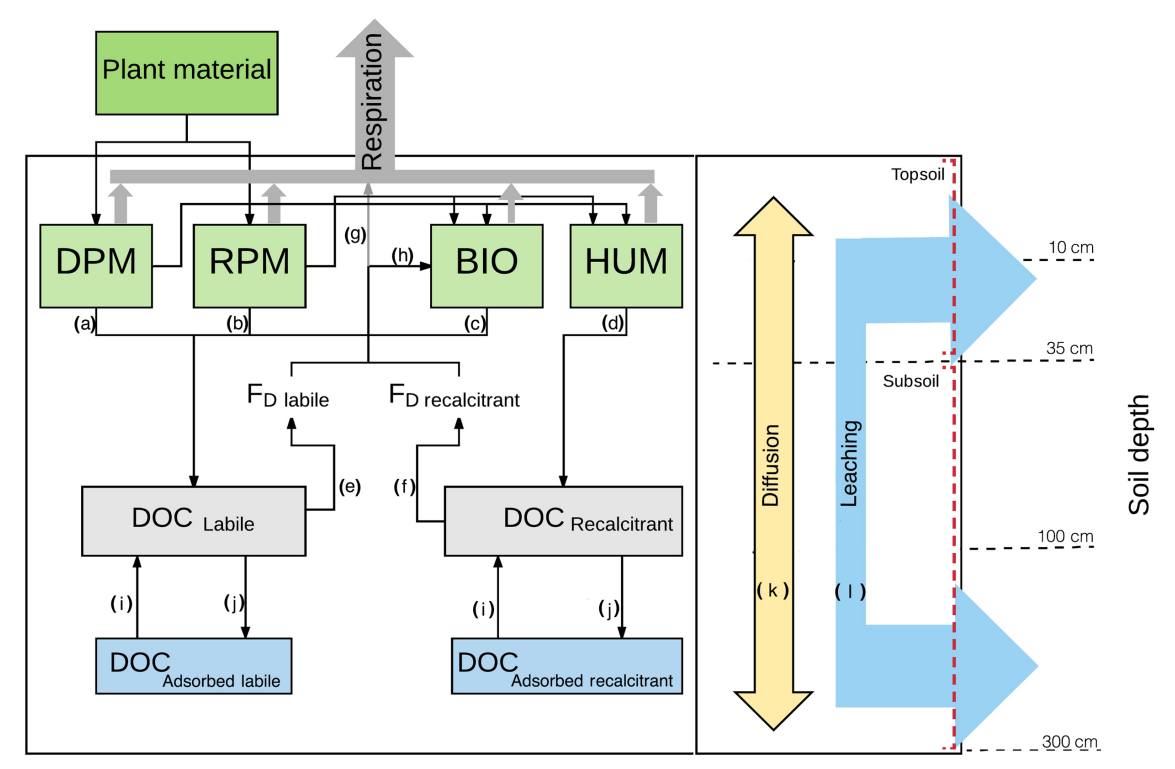

Figure 1. JULES-DOCM model structure.

$$
\begin{aligned}
& +\sum_{i=1}^{i=4} F_{\mathrm{BIO}_{\mathrm{IN}_{i}}}, \\
& \frac{\Delta S_{\mathrm{C}_{\mathrm{HUM}}}}{\Delta t}=0.54\left(1-B_{\mathrm{R}}\right) R_{\mathrm{S}}-R_{\mathrm{HUM}}-\sum_{i=1}^{i=4} F_{\mathrm{P}_{\mathrm{HUM}_{i}}},
\end{aligned}
$$

where in the RothC model the fraction $\left(f_{\mathrm{DPM}}\right)$ of litterfall $\left(\Lambda_{c}\right)$ is directed to DPM and RPM depending on vegetation type. $\mathrm{C}$ pools are subjected to decomposition. Part of decomposed $\mathrm{C}$ as a fraction $\left(1-B_{\mathrm{R}}\right)$ of total respiration $\left(R_{\mathrm{S}}=R_{\mathrm{DPM}}+R_{\mathrm{RPM}}+R_{\mathrm{BIO}}+R_{\mathrm{HUM}}+R_{\mathrm{DOC}}\right)$ is partially feeding microorganisms in soil (BIO) and partially stored as recalcitrant $\mathrm{C}$ in soil (HUM) depending on soil texture and the rest $\left(B_{\mathrm{R}}\right)$ is released to the atmosphere. These parameters were already present in JULES (Clark et al., 2011). In JULES-DOCM the update of carbon pools after DOC production was added (last term of each equation, $F_{\mathrm{P}}$..., defined in Eq. 4 above) as was $F_{\mathrm{BIO}_{\mathrm{IN}}}$ the input flux from the DOC to $\mathrm{BIO}$ pool, as described below.

We assume that the decomposition of DOC pools $\left(F_{\mathrm{D}}\right.$; $\mathrm{kg} \mathrm{C} \mathrm{m}{ }^{-2}$ day $^{-1}$ ) also follows first-order kinetics depending on temperature and labile and recalcitrant DOC pool size as follows (arrows e-f in Fig. 1):

$F_{\mathrm{D}_{k, i}}=S_{\mathrm{DOC}_{k, i}} \cdot\left(1-e^{\left(-K_{\left.\mathrm{DOC}_{k} \cdot F_{\mathrm{T}}\left(T_{\mathrm{soil}}\right)_{i}\right)}\right)}\right)$,

where $S_{\mathrm{DOC}_{i}}$ is the DOC pool size ( $k$ for labile or recalcitrant) in $\mathrm{kg} \mathrm{C} \mathrm{m}^{-2}, K_{\mathrm{DOC}_{k}}$ is the basal decomposition rate of the dissolved DOC ( $k$ for labile or recalcitrant pool; in day $\left.^{-1}\right)$, and $F_{\mathrm{T}}\left(T_{\text {soil }}\right)_{i}$ is the soil temperature rate modifier within each soil layer $(i)$ as in Eq. (4).

Part of decomposed DOC is respired $\left(R_{\mathrm{DOC}}\right.$ in $\mathrm{kg} \mathrm{C} \mathrm{m}^{-2}$ day $^{-1}$, arrow $\mathrm{g}$ in Fig. 1) and the rest returns to the $\mathrm{BIO}$ carbon pool $\left(F_{\mathrm{BIO}_{\mathrm{IN}}}\right.$ in $\mathrm{kg} \mathrm{C} \mathrm{m}^{-2}$ day ${ }^{-1}$, arrow $\mathrm{h}$ in Fig. 1) from each soil layer $(i)$ and DOC pools $(k)$. This proportion is controlled by a CUE parameter (Kalbitz et al., 2003) which is set to 0.5 as a default as in Manzoni et al. (2012).

Hence the distribution of decomposed DOC to the BIO pool and respiration will be

$$
\begin{aligned}
& F_{\mathrm{BIO}_{\mathrm{IN}}}=(1-\mathrm{CUE}) \cdot \sum F_{\mathrm{D}_{k, i}}, \\
& R_{\mathrm{DOC}_{k, i}}=\mathrm{CUE} \cdot \sum F_{\mathrm{D}_{k, i}} .
\end{aligned}
$$

For adsorption and desorption, a constant sorption equilibrium distribution coefficient $\left(K_{\mathrm{D}}\right)$ is used to partition DOC in dissolved and adsorbed phases. The assumption is that DOC in the labile or recalcitrant pool is proportionally distributed between adsorbed DOC $\left(S_{\mathrm{DOC}_{\mathrm{ad}}}\right)$ and dissolved DOC pools ( $S_{\mathrm{DOC}}$ in soluble phase) depending on $K_{\mathrm{D}}$ from each soil layer $(i)$ and DOC pool $(k)$. Hence if the potentially adsorbed DOC fraction (AD_pot ${ }_{i}$ ) compared to the size of the actually adsorbed DOC $\left(S_{\mathrm{DOC}_{\mathrm{ad}}, i}\right)$ is positive then this fraction will be adsorbed and added to the adsorbed DOC pool, and if it is negative then this fraction will be desorbed and added to the dissolved DOC pool per model time step.

These terms for DOC labile and recalcitrant pools in JULES-DOCM are as follows (arrows i and j, Fig. 1):

$$
\begin{aligned}
& {\mathrm{AD} \_p_{i}}_{i}=S_{\mathrm{DOC}_{k, i}} \cdot K_{\mathrm{D}} \cdot \frac{\mathrm{BK}}{\theta v_{i}}, \\
& S_{\mathrm{DOC}_{k, i}}=S_{\mathrm{DOC}_{k, i}}-\left(\mathrm{AD} \_\mathrm{pot}_{i}-S_{\mathrm{DOC}_{\mathrm{ad}}{ }_{k, i}}\right), \\
& S_{\mathrm{DOC}_{\mathrm{ad}_{k, i}}}=S_{\mathrm{DOC}_{\mathrm{ad}_{k, i}}}+\left(\mathrm{AD} \_\mathrm{pot}_{i}-S_{\mathrm{DOC}_{\mathrm{ad}_{k, i}}}\right),
\end{aligned}
$$

where $S_{\mathrm{DOC}_{k, i}}$ is dissolved labile and recalcitrant DOC pools in $\mathrm{kg} \mathrm{C} \mathrm{m}^{-2}, K_{\mathrm{D}}$ is the distribution factor $\left(\mathrm{m}^{3}\right.$ water $\mathrm{kg}^{-1}$ soil $), \quad \mathrm{BK}$ is bulk density $\left(\mathrm{kg} \mathrm{soil} \mathrm{m}^{-3}\right)$, 
and $\theta_{\mathrm{v}_{i}}$ is the volumetric soil moisture $\left(\mathrm{m}^{3} \mathrm{~m}^{-3}\right)$ and it is considered to be the same for DOC labile and recalcitrant pools.

DOC diffusion $\left(F_{\text {Diff }_{i, j}}\right)$ in $\mathrm{kg} \mathrm{C} \mathrm{m}^{-2} \mathrm{day}^{-1}$ between the layers is based on Fick's second law and it is the function of the diffusion coefficient $(D)$ in $\mathrm{m}^{2} \mathrm{day}^{-1}$, the concentration of labile or recalcitrant DOC at different soil depths $\left(C_{\mathrm{DOC}_{k, i, j}}\right)$ in $\mathrm{kg} \mathrm{Cm}^{-2}$, and the distance $\left(z_{i, j}\right)$ between the midpoints of soil layers ( $i$ : downward flow; $j$ : upward flow) in metres (arrow k, Fig. 1):

$F_{\mathrm{Diff}_{i, j}}=D \cdot \frac{\partial^{2} C_{\mathrm{DOC}_{k, i, j}}}{\partial z_{i, j}{ }^{2}}$.

Leaching of the DOC is considered to occur from all four DOC soil layers. The top DOC is defined as the first two layers representing the first $35 \mathrm{~cm}$ of the soil. The lower two DOC layers represent the subsoil from $35 \mathrm{~cm}$ down to $3 \mathrm{~m}$. Soil leaching at the top DOC layer is dependent on the surface run-off, whereas subsurface leaching is dependent on the subsurface run-off. However, subsurface run-off also represents the drainage from the bottom of the $3 \mathrm{~m}$ soil column and thus mimics the groundwater base flow in terms of water and in terms of DOC exports. More information on the hydrology of the model is given in Gedney and Cox (2003) and Clark and Gedney (2008). Both DOC layer leaching fluxes are based on the concentration of dissolved DOC in the soil water. Hence, the leaching of DOC $(L)$ from the dissolved labile and recalcitrant pool within the topsoil (sum of first and second soil layer) and subsoil (sum of third and fourth soil layer; $T$ and $S$ ) in $\mathrm{kg} \mathrm{C} \mathrm{m}^{-2}$ day $^{-1}$ is calculated as follows (arrow 1, Fig. 1):

$L_{\mathrm{T}}=S_{\mathrm{DOC}_{k, h}} \cdot \frac{\text { Roff }_{\text {surf }}}{T_{\mathrm{S}_{i}}}$,

$L_{\mathrm{S}}=S_{\mathrm{DOC}_{k, h}} \cdot \frac{\text { Roff }_{\mathrm{sub}}}{T_{\mathrm{S}_{i}}}$,

where $S_{\mathrm{DOC}_{k, h}}$ is the DOC quantity in the dissolved labile and recalcitrant pool ( $h$ for topsoil or subsoil), Roff surf is $_{\text {in }}$ the surface run-off, Roff sub $_{\text {is }}$ the subsurface run-off (both $\mathrm{kg} \mathrm{m}^{-2} \mathrm{day}^{-1}$ ), and $T_{\mathrm{s}_{i}}$ (defined in code as $\theta_{\mathrm{s}}$ ) is the soil moisture in each soil layer $\left(i ; \mathrm{kg} \mathrm{m}^{-2}\right)$.

Hence the dissolved and adsorbed DOC pools are updated as follows:

$\frac{\Delta S_{\mathrm{DOC}_{k}}}{\Delta t}=F_{\mathrm{P}_{k, i}}+\mathrm{AD} \_\mathrm{pot}_{i}+F_{\mathrm{Diff}_{i}}-F_{\mathrm{D}_{k, i}}-L_{\mathrm{T}}-L_{\mathrm{S}}$.

Values of the default DOC model parameters are given in Table 1.

\subsection{Sites description}

Two data levels were provided in order to test the model performance. Level 1, for Hainich, Carlow, and Brasschaat, included the carbon fluxes and continuous DOC measurements from soil water from a 3- to 10-year period, and Level 2, for Turkey Point 89 (TP89) and Guandaushi, showed fewer $\mathrm{C}$ flux measurements and discontinuous DOC measurements (Table 3). The locations of the sites are given in Fig. 2.

\subsubsection{Hainich}

The site Hainich, located in Germany within Hainich National Park $\left(51^{\circ} 04^{\prime} 45^{\prime \prime} \mathrm{N}, 10^{\circ} 27^{\prime} 07^{\prime \prime} \mathrm{E}\right)$, is covered by an oldgrowth deciduous forest dominated by Fagus sylvatica and intermixed with Fraxinus excelsior and Acer pseudoplatanus (Mund et al., 2010). The soil class at this site is Eutric Cambisol with a high clay content and high biological activity, as illustrated by a mull or F-mull organic layer (Table 4). The mean annual air temperature is $7.5-8^{\circ} \mathrm{C}$ and the annual precipitation is in the range of $750-800 \mathrm{~mm} \mathrm{yr}^{-1}$ (Kutsch et al., 2010). At this site, soil solution samples were taken at three depths $(5,10$, and $20 \mathrm{~cm})$ using ceramic suction plates positioned at four different plots within the site. Samples were obtained by applying a tension of $100 \mathrm{hPa}$ after each biweekly sampling occasion.

\subsubsection{Carlow}

The site Carlow is located in Ireland in County Carlow $\left(52^{\circ} 52^{\prime} \mathrm{N}, 6^{\circ} 54^{\prime} \mathrm{W}\right)$. The land cover is grassland, and the soil class is Calcic Luvisol. This sandy loamy soil has a uniform profile and is well drained (Table 4). The climate is characterized by a mean annual air temperature of $9.3^{\circ} \mathrm{C}$ and a mean annual precipitation of $823 \mathrm{~mm} \mathrm{yr}^{-1}$ (Walmsley et al., 2011). DOC samples were collected from two locations separated $150 \mathrm{~m}$ from each other using 20 suction cups per location, with 10 of these cups installed directly beneath the rooting zone and the other 10 at a depth of $0.7 \mathrm{~m}$. Samples were obtained by applying a tension of $400 \mathrm{hPa}$ after each biweekly sampling occasion (Walmsley, 2009).

\subsubsection{Brasschaat}

The site Brasschaat is located in Belgium and covered by mixed coniferous and deciduous (De Inslag) forest, $\left(51^{\circ} 18^{\prime} 33^{\prime \prime} \mathrm{N}, 4^{\circ} 31^{\prime} 14^{\prime \prime} \mathrm{E}\right)$ with stands of old Scots pine ( $P i$ nus sylvestris; Janssens et al., 1999). The temperate maritime climate is characterized by a mean annual air temperature of $11.1^{\circ} \mathrm{C}$ and a mean annual precipitation of $824 \mathrm{~mm} \mathrm{yr}^{-1}$ (Gielen et al., 2010). The soil class was defined as Albic Hypoluvic Arenosol (Table 4). The profile usually exhibits a high soil moisture, but due to the sandy texture and rapid hydraulic conductivity in the upper horizons, it is rarely saturated (Gielen et al., 2011).

DOC samples were collected at three horizons of Al-Ap, A-E, and Cg (Soil Classification Working Group, 1998) referring to 10,35 , and $75 \mathrm{~cm}$ of depth by means of ceramic suction cups on a biweekly interval. Two days prior to sample collection a tension of $600 \mathrm{hPa}$ was applied to each suction cup. Samples were collected at three locations and pooled 
Table 1. DOC-relevant parameters in the JULES-DOCM model.

\begin{tabular}{|c|c|c|c|c|c|}
\hline Parameter & Description & Value & Unit & \multicolumn{2}{|c|}{ Sensitivity test values $( \pm)$} \\
\hline \multicolumn{6}{|c|}{ Carbon parameters } \\
\hline$z_{0}$ & $\begin{array}{l}e \text {-folding depth of carbon content } \\
\text { within } 1 \mathrm{~m} \text { of soil }\end{array}$ & $\begin{array}{r}\text { Values range } \\
(65.68-167.13)\end{array}$ & $\mathrm{m}^{-1}$ & PFT based & 109.55 \\
\hline$\tau_{\zeta}$ & $\begin{array}{l}\text { Decay of carbon decomposition } \\
\text { with depth }(\mathrm{z})^{\mathrm{b}}\end{array}$ & 2 & $\mathrm{~m}^{-1}$ & 3 & \\
\hline \multicolumn{6}{|c|}{ DOC parameters } \\
\hline$K_{\mathrm{P}}$ & $\begin{array}{l}\text { Rate constant for DOC production } \\
\text { specific to each carbon pool }\end{array}$ & $\begin{array}{l}1 \times 10^{-4}, 5 \times 10^{-6} \\
5 \times 10^{-5}, 2 \times 10^{-6}\end{array}$ & day $^{-1}$ & - & - \\
\hline$K_{\text {DOC (labile) }}$ & $\begin{array}{l}\text { Basal decomposition rate of dissolved } \\
\text { DOC labile pool }\end{array}$ & $\begin{array}{r}3 \\
\text { Value range }(0.46-100)\end{array}$ & days & 4.5 & 1.5 \\
\hline$K_{\text {DOC (recalcitrant) }}$ & $\begin{array}{l}\text { Basal decomposition rate of dissolved } \\
\text { DOC recalcitrant pool }\end{array}$ & $\begin{array}{r}600.0 \\
\text { Value range }(66-5000)\end{array}$ & days & 900 & 300 \\
\hline $\begin{array}{l}\text { Slope parameter } \\
\text { of } D_{\mathrm{f}}\end{array}$ & $\begin{array}{l}\text { Slope parameter controlling DOC } \\
\text { production and decomposition modifier } \\
\text { depending on clay and silt fraction }{ }^{\mathrm{f}}\end{array}$ & 0.75 & - & 1 & 0.5 \\
\hline CUE & Carbon use efficiency ${ }^{\mathrm{g}}$ & 0.5 & - & 0.75 & 0.25 \\
\hline$K_{\mathrm{D}}$ & $\begin{array}{l}\text { Distribution coefficient of } \\
\text { of adsorbed DOC }\end{array}$ & $8.05 \times 10^{-6}$ & $\mathrm{~m}^{3}$ water $\mathrm{kg}^{-1}$ soil & $1.21 \times 10^{-4}$ & $4.03 \times 10^{-6}$ \\
\hline$D$ & DOC diffusion coefficient ${ }^{\mathrm{i}}$ & $1.06 \times 10^{-5}$ & $\mathrm{~m}^{2}$ day $^{-1}$ & $1.59 \times 10^{-5}$ & $5.31 \times 10^{-6}$ \\
\hline
\end{tabular}

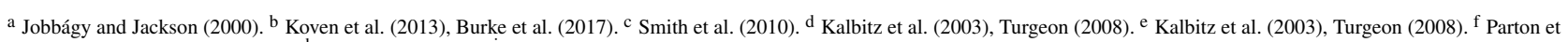
al. (1987). ${ }^{\mathrm{g}}$ Manzoni et al. (2012). ${ }^{\mathrm{h}}$ Moore et al. (1992). ${ }^{\mathrm{i}}$ Ota et al. (2013).

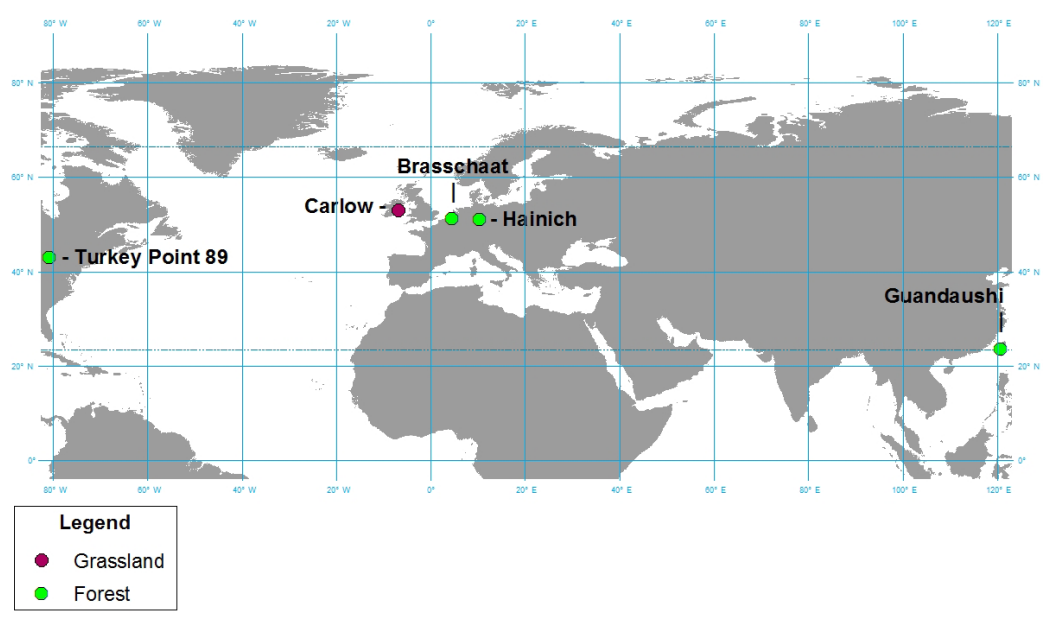

Figure 2. Study sites.

into one composite sample per layer for analysis (Gielen et al., 2011).

\subsubsection{Turkey Point 89}

The site Turkey Point 89 (TP89), located in southern Ontario, Canada $\left(42^{\circ} 77^{\prime} 57^{\prime \prime} \mathrm{N}, 80^{\circ} 45^{\prime} 09^{\prime \prime} \mathrm{E}\right)$, is covered by an evergreen needle-leaf forest dominated by eastern white pine ( $P i$ nus strobus L.) mixed with a few stands of oak, paper birch, wild black cherry, and red pine (Peichl and Arain 2006) established in 1989 on agricultural lands (Peichl et al., 2010b). The mean annual air temperature is $8.1^{\circ} \mathrm{C}$ and mean annual precipitation is $832 \mathrm{~mm} \mathrm{yr}^{-1}$ (Peichl and Arain, 2006). The soil class at this site is Gleyed Brunisolic Luvisol and due to the high sand content, it is well drained and has a low to moderated water-holding capacity (Peichl et al., 2010b; Presant and Acton, 1984). DOC sampling was attempted in monthly intervals at three depths of 25,50 , and $100 \mathrm{~cm}$ by means of porous suction cups; however, due to the dry sandy soils, samples could only be retrieved for 5 separate days of sampling after heavy rainfall events on 29 November 2004, 3 May 2005, 16 and 29 June 2005, and 14 October 2005 (Peichl et al., 2007). 
Table 2. Symbol definitions and units.

\begin{tabular}{|c|c|c|}
\hline Symbol & Units & Definition \\
\hline BK & $\mathrm{kg} \mathrm{m}^{-3}$ & Bulk density \\
\hline$B_{\mathrm{R}}$ & & Fraction of soil respiration which is respired \\
\hline$\beta_{z}$ & $\mathrm{~m}^{-1}$ & Carbon distribution with depth depending on biome \\
\hline CUE & & Carbon use efficiency \\
\hline$C_{\mathrm{DOC}}$ & $\mathrm{kgC} \mathrm{m}^{-2}$ & Amount of DOC subjected to transport by diffusion \\
\hline$D$ & $m^{2}$ day $^{-1}$ & DOC diffusion coefficient \\
\hline$D_{\mathrm{f}}$ & & DOC production and decomposition modifier depending on clay and silt fraction \\
\hline $\mathrm{dz}$ & $\mathrm{m}$ & Soil layer thickness \\
\hline$\Delta S_{\mathrm{C}_{\mathrm{BIO}}}$ & $\mathrm{kgC} \mathrm{m}^{-2}$ day $^{-1}$ & Biomass carbon pool update \\
\hline$\Delta S_{\mathrm{C}_{\mathrm{DPM}}}$ & $\mathrm{kgC} \mathrm{m}^{-2}$ day $^{-1}$ & Decomposable plant material carbon pool update \\
\hline$\Delta S_{\mathrm{CHUM}_{\mathrm{HU}}}$ & $\mathrm{kg} \mathrm{C} \mathrm{m}^{-2}$ day $^{-1}$ & Humus carbon pool update \\
\hline$\Delta S_{\mathrm{C}_{\mathrm{RPM}}}$ & $\mathrm{kg} \mathrm{C} \mathrm{m}^{-2}$ day $^{-1}$ & Resistant plant material carbon pool update \\
\hline$\Delta S_{\mathrm{DOC}}$ & $\mathrm{kg} \mathrm{C} \mathrm{m}^{-2}$ day $^{-1}$ & Labile and recalcitrant DOC pools update \\
\hline AD_pot & $\mathrm{kgC} \mathrm{m}^{-2}$ day $^{-1}$ & Adsorbed or desorbed DOC from labile and recalcitrant pools \\
\hline$F_{\mathrm{BIO}_{\text {IN }}}$ & $\mathrm{kgC} \mathrm{m}^{-2}$ day $^{-1}$ & Decomposed DOC flux from labile and recalcitrant pool into biomass pool \\
\hline$F_{\mathrm{D}}$ & $\mathrm{kg} \mathrm{C} \mathrm{m}^{-2}$ day $^{-1}$ & Labile and recalcitrant decomposed DOC flux \\
\hline$F_{\text {Diff }}$ & $\mathrm{kg} \mathrm{C} \mathrm{m}^{-2}$ day $^{-1}$ & Flux of DOC transported by diffusion \\
\hline$F_{\mathrm{P}_{\mathrm{BIO}}}$ & $\mathrm{kgC} \mathrm{m}^{-2}$ day $^{-1}$ & DOC flux originated from biomass carbon pool \\
\hline$F_{\mathrm{P}_{\mathrm{DPM}}}$ & $\mathrm{kg} \mathrm{C} \mathrm{m}^{-2}$ day $^{-1}$ & DOC flux originated from decomposable plant material carbon pool \\
\hline$F_{\mathrm{PHUM}_{\mathrm{HU}}}$ & $\mathrm{kg} \mathrm{C} \mathrm{m}^{-2}$ day $^{-1}$ & DOC flux originated from humus carbon pool \\
\hline$F_{\mathrm{P}_{\mathrm{RPM}}}$ & $\mathrm{kg} \mathrm{C} \mathrm{m}^{-2}$ day $^{-1}$ & DOC flux originated from resistant plant material carbon pool \\
\hline$F_{\mathrm{S}}(s)$ & $\mathrm{kg} \mathrm{m}^{-2}$ & Soil moisture rate modifier \\
\hline$F_{\mathrm{T}}\left(T_{\text {soil }}\right)$ & $\mathrm{K}$ & Soil temperature rate modifier \\
\hline$F_{\mathrm{V}}(v)$ & & Fractional coverage of a vegetation type \\
\hline$f_{\mathrm{dpm}}$ & & Fraction of litter that is decomposable plant material \\
\hline$K_{\mathrm{P}}$ & day $^{-1}$ & Rate constant for DOC production specific to the pool \\
\hline$K_{\mathrm{DOC}}$ & days & Basal decomposition rate of dissolved DOC labile and recalcitrant pools \\
\hline$K_{\mathrm{D}}$ & $\mathrm{m}^{3}$ water $\mathrm{kg}^{-1}$ soil & Distribution coefficient of adsorbed DOC \\
\hline$\Lambda_{\mathrm{c}}$ & $\mathrm{kgC} \mathrm{m}^{-2}$ day $^{-1}$ & Litterfall rate \\
\hline$L_{\mathrm{T}}$ & $\mathrm{kg} \mathrm{m}^{-2}$ day $^{-1}$ & Leaching from labile and recalcitrant DOC pools in topsoil \\
\hline$L_{\mathrm{S}}$ & $\mathrm{kg} \mathrm{m}^{-2}$ day $^{-1}$ & Leaching from labile and recalcitrant DOC pools in subsoil \\
\hline$m$ & & DOC decomposition rate type (labile or recalcitrant) \\
\hline$R_{\mathrm{BIO}}$ & $\mathrm{kg} \mathrm{C} \mathrm{m}^{-2}$ day $^{-1}$ & Respiration from biomass carbon pool \\
\hline$R_{\mathrm{DPM}}$ & $\mathrm{kgC} \mathrm{m}^{-2}$ day $^{-1}$ & Respiration from decomposable plant material carbon pool \\
\hline$R_{\mathrm{DOC}}$ & $\mathrm{kgC} \mathrm{m}^{-2}$ day $^{-1}$ & Respiration from labile and recalcitrant DOC pools \\
\hline$R_{\mathrm{HUM}}$ & $\mathrm{kg} \mathrm{C} \mathrm{m}^{-2}$ day $^{-1}$ & Respiration from humus carbon pool \\
\hline$R_{\mathrm{RPM}}$ & $\mathrm{kg} \mathrm{C} \mathrm{m}^{-2}$ day $^{-1}$ & Respiration from resistant plant material carbon pool \\
\hline Roff $_{\text {surf }}$ & $\mathrm{kg} \mathrm{m}^{-2}$ day $^{-1}$ & Surface run-off \\
\hline Roff $_{\text {sub }}$ & $\mathrm{kg} \mathrm{m}^{-2}$ day $^{-1}$ & Subsurface run-off \\
\hline$S_{\mathrm{C}}$ & $\mathrm{kgCm}^{-2}$ & Soil carbon storage \\
\hline$T_{\mathrm{S}}$ & $\mathrm{kg} \mathrm{m}^{-2}$ & Soil moisture content \\
\hline$S_{\mathrm{DOC}}$ & $\mathrm{kgC} \mathrm{m}^{-2}$ & Labile and recalcitrant DOC storages \\
\hline$S_{\mathrm{DOC}_{\mathrm{ad}}}$ & $\mathrm{kgCm}^{-2}$ & Adsorbed labile and recalcitrant DOC storages \\
\hline$\theta_{\mathrm{V}}$ & $\mathrm{kg} \mathrm{m}^{-3}$ & Volumetric soil moisture content \\
\hline$\tau_{z}$ & $\mathrm{~m}^{-1}$ & Decay of carbon decomposition with depth \\
\hline$z$ & $\mathrm{~m}$ & Soil depth \\
\hline$z_{0}$ & $\mathrm{~m}$ & $e$-folding depth of carbon content within $1 \mathrm{~m}$ of soil \\
\hline
\end{tabular}

\subsubsection{Guandaushi}

The site Guandaushi is located in central Taiwan $\left(23^{\circ} 8^{\prime} \mathrm{N}\right.$, $\left.120^{\circ} 8^{\prime} \mathrm{E}\right)$. The climate is characterized by distinct rainy and dry seasons, a mean annual air temperature of $22.4^{\circ} \mathrm{C}$, and annual precipitation in the range of 2300 to $2700 \mathrm{~mm} \mathrm{yr}^{-1}$. The land cover is subtropical mixed hardwood forest including three stands of natural hardwood and secondary hard- 
Table 3. Data availability for model evaluation at different sites.

\begin{tabular}{|c|c|c|c|c|c|}
\hline Sites & Brasschaat $^{\mathrm{a}}$ & Carlow $^{\mathrm{a}}$ & Guandaushi $^{\mathrm{b}}$ & Hainich $^{\mathrm{a}}$ & Turkey Point $89^{b}$ \\
\hline \multicolumn{6}{|c|}{ Carbon fluxes } \\
\hline GPP & 2000-2006 & 2008 & & $2000-2012$ & 2005-2008 \\
\hline NPP & 2000 & & & $2000-2007$ & 2005-2008 \\
\hline Soil respiration & 2000-2006 & & & 2000-2007 & 2005-2008 \\
\hline $\mathrm{C}$ content & 1995-1998 & 2006-2009 & & 2000-2007 & 2004-2006 \\
\hline \multicolumn{6}{|c|}{ DOC measurements } \\
\hline 1 year & & & 1999 & & \\
\hline 1 to 5 years & & 2006-2009 & & & 2004-2005 \\
\hline 5 to 10 years & 2000-2008 & & & 2001-2014 & \\
\hline
\end{tabular}

${ }^{\mathrm{a}}$ Level 1 site. ${ }^{\mathrm{b}}$ Level 2 site.

Table 4. Evaluation Level 1 site characteristics.

\begin{tabular}{|c|c|c|c|}
\hline & \multicolumn{3}{|c|}{ Site } \\
\hline & Brasschaat & Carlow & Hainich \\
\hline & \multicolumn{3}{|c|}{ Characteristics } \\
\hline Ecosystem & $\begin{array}{r}\text { Evergreen } \\
\text { forest }\end{array}$ & Grassland & $\begin{array}{r}\text { Deciduous } \\
\text { forest }\end{array}$ \\
\hline Soil classification & Arenosol & Luvisol & Cambisols \\
\hline $\mathrm{BK}\left(\mathrm{kg} \mathrm{m}^{-3}\right)$ & 1.4 & 1.07 & 1.2 \\
\hline Clay (fraction) & 0.034 & 0.22 & 0.589 \\
\hline Sand (fraction) & 0.8912 & 0.51 & 0.031 \\
\hline \multirow[t]{2}{*}{ Silt (fraction) } & 0.0748 & 0.27 & 0.38 \\
\hline & \multicolumn{3}{|c|}{ Measurement depth $(\mathrm{cm})$} \\
\hline Carbon content & $100^{\mathrm{a}}$ & $50^{\mathrm{b}}$ & $60^{\mathrm{c}}$ \\
\hline \multirow[t]{2}{*}{ DOC concentration } & $10,35,75$ & $5,10,20$ & $10-77$ \\
\hline & \multicolumn{3}{|c|}{ FLUXNET meteorological observations } \\
\hline Period & 1996-2014 & 2004-2014 & 2004-2009 \\
\hline
\end{tabular}

wood on light loam textured soil and Chinese fir (Cunninghamia lanceolate) on heavy clay textured soil. DOC samples were collected at three depths of 15,30 , and $60 \mathrm{~cm}$ in three locations at biweekly interval by means of ceramic suction cups.

\subsection{Model input and setting}

Model performance was tested against observed data from Guandaushi and four FLUXNET sites (Hainich, Carlow, Brasschaat, and Turkey Point 89). The FLUXNET database provides on-site meteorological data for each site that could be used as forcing for simulations in JULES. However, we had to use the global WATCH dataset (Weedon et al., 2010) as forcing for the Guandaushi site where no on-site data were available. Forcing data were checked for any missing information and they were gap filled by linear interpolation.
The meteorological forcing is provided at the measurement site level (no explicit spatial resolution) and includes the downward shortwave and longwave radiation at the surface $\left(\mathrm{W} \mathrm{m}^{-2}\right)$, rainfall $\left(\mathrm{kg} \mathrm{m}^{-2} \mathrm{~s}^{-1}\right)$, snowfall $\left(\mathrm{kg} \mathrm{m}^{-2} \mathrm{~s}^{-1}\right)$, wind speed $\left(\mathrm{m} \mathrm{s}^{-1}\right)$, atmospheric temperature $(\mathrm{K})$, atmospheric specific humidity $\left(\mathrm{kg} \mathrm{kg}^{-1}\right)$, and air pressure at the surface (Pa) at a 30 min time step (Best et al., 2011).

For Brasschaat, additional model parameters such as BK and clay were taken from Janssens et al. (1999). The model was first spun up looping over the period 1996-2014 until all the soil variables reached a steady state. For Hainich, site parameters were taken from Kutsch et al. (2010). The spinup was run looping 300 times over the years 2004-2014. For Carlow, site parameters were taken from Walmsley (2009) and Kindler et al. (2010). The spin-up was run looping 300 times over the years 2004-2009. For Turkey Point 89, site parameters were taken from Peichl and Arain (2006) and spin-up was run looping 300 times over the years 2002-2007. For Guandaushi, site vegetation parameters were taken from Liu and Sheu (2003) and soil parameters from HWSD global data (Nachtergaele et al., 2010); spin-up was run looping 300 times over years 1990-2000. The evaluation of the model was performed on the plot scale using climate forcing data, soil, and land cover consistent with the site, and no horizontal spatial dimension was involved.

\subsection{Sensitivity test}

In order to test the sensitivity of DOC-related model parameters on the DOC concentration in different depths of the soil profile, simulations were performed with varying values for $z_{0}, \tau_{z}$, and DOC controlling parameters such as $K_{\mathrm{DOC} \text { (labile) }}$,

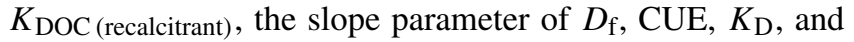
$D$ (Table 1).

In total, 16 runs were performed by modifying each parameter once by increasing it $50 \%$ and once by decreasing it by $50 \%$, except for the slope parameter controlling $D_{\mathrm{f}}$ (Eq. 5), which was changed by $33 \%$ to remain within 
the physical boundaries. In order to do the comparison with measurements, runs were performed for $3 \mathrm{~m}$ of soil depth for the periods that measurements were available. Hence, Brasschaat runs were performed for the years 2006-2010, Hainich runs for the years 2005-2014, and Carlow runs for the years 2006-2008

\subsection{Statistical analysis}

In order to test the model performance with regard to simulated $\mathrm{C}$ stock and fluxes, we used an ANOVA (analysis of variance) test to compare the model results from the default set of parameters against measurements. In order to test the parameter impact on the simulated DOC concentrations, we computed the RMSE values from each set of model parameter configurations.

\section{Results}

\subsection{Validation of carbon concentration and fluxes}

To examine the performance of soil DOC simulations, it is first necessary to explore other carbon fluxes which link to soil DOC pools. The first flux to be validated is the gross primary production (GPP), for which we have observed values (Table 3). The modelled mean GPP for Brasschaat and Carlow was significantly lower than measurements with $867 \pm 25 \mathrm{~g} \mathrm{C} \mathrm{m}^{-2}$ year $^{-1}$ compared to $1173.3 \pm 91$ and 903.2 $\mathrm{g} \mathrm{C} \mathrm{m}^{-2}$ year ${ }^{-1}$ compared to $1165.3 \mathrm{~g} \mathrm{C} \mathrm{m}^{-2}$ year $^{-1}$ $(p<0.05$, Table S3), respectively. For Turkey Point 89 and Hainich, the measured GPP was in line with our model results with $1731.5 \pm 108$ and $1606.74 \pm 101 \mathrm{~g} \mathrm{C} \mathrm{m}^{-2}$ year $^{-1}$ compared to $1635.1 \pm 62$ and $1455 \pm 167 \mathrm{~g} \mathrm{C} \mathrm{m}^{-2}$ year $^{-1}$ ( $p=0.162$, Table S3). The modelled NPP was higher than observed values for Hainich and for Turkey Point 89, while it was lower than observed values for Brasschaat (Table 5).

Total soil respiration measurements were available for Brasschaat, Hainich, and Turkey Point 89 (Table 3) and were compared with the modelled outputs. The simulated values were close to observed values at Hainich, while the modelled values for Brasschaat were significantly higher ( $p$ value $<0.05$, Table S3) and those for Turkey Point 89 were higher $(p$ value $=0.0896$, Table S3) than the observed values (Table 5).

Finally, we compared the SOC in measurements and model outputs; measurements from Brasschaat for $100 \mathrm{~cm}$, Hainich for $60 \mathrm{~cm}$, Carlow for $50 \mathrm{~cm}$, and Turkey Point 89 for $15 \mathrm{~cm}$ (A horizon) of soil were available. The modelled SOC stock for Brasschaat in the first $100 \mathrm{~cm}$ and for Hainich down to $60 \mathrm{~cm}$ were slightly lower than the observations, while for Carlow the simulated stocks down to $50 \mathrm{~cm}$ and for Turkey Point 89 the simulated stocks down to $15 \mathrm{~cm}$ were higher than the observed stocks (Table 5).
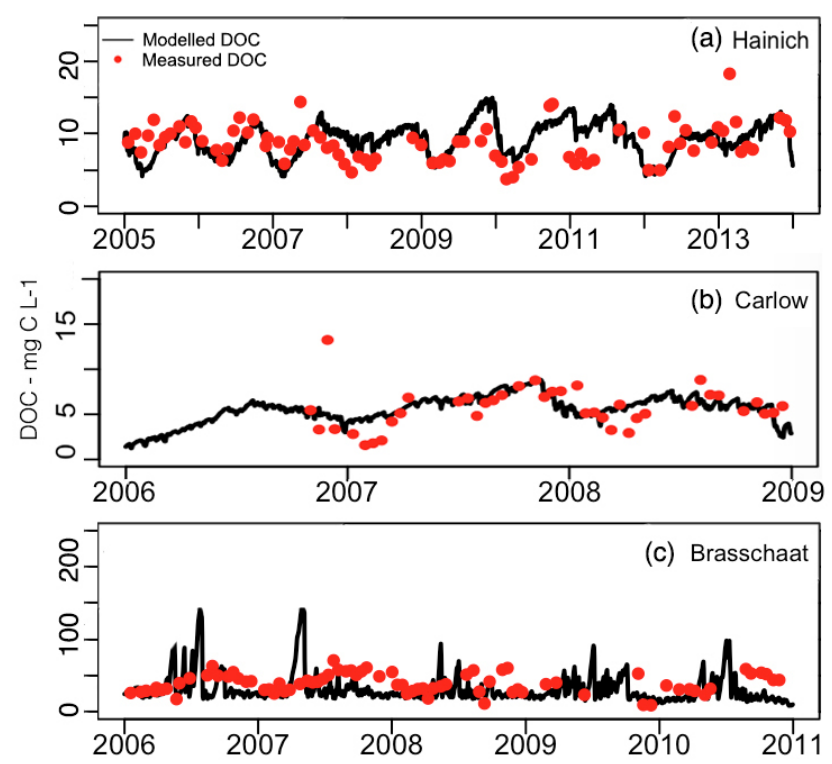

Figure 3. DOC concentration $\left(\mathrm{mg} \mathrm{C} \mathrm{L}^{-1}\right)$ at $10 \mathrm{~cm}$ of depth measured (red dots) and simulated (black lines) for (a) Hainich, (b) Carlow, and (c) Brasschaat. Results for other depths are given in Fig. S2.

\subsection{DOC simulations}

In general, JULES-DOCM was capable of reproducing the DOC concentrations at all the tested sites using the default set of parameters (Table 1) chosen as representative of the topsoil (Fig. 3 Level 1 sites, Fig. 4 Level 2 sites). For Hainich, the simulated average values and value range were close to observed values at 10 and $20 \mathrm{~cm}$ (Table 5; RMSE values for 10 and $20 \mathrm{~cm}$ are 3.0 and $2.5 \mathrm{mg} \mathrm{L}^{-1}$, respectively). For Brasschaat, the simulation underestimated DOC concentrations at all depths, but with an increasing underestimation with soil depth (Table 5; RMSE values for 10,35 , and $75 \mathrm{~cm}$ are $22.9,18.4$, and $16.8 \mathrm{mg} \mathrm{L}^{-1}$, respectively). For Carlow, the modelled and measured values were close at depths of 10 and $77 \mathrm{~cm}$, but strongly underestimated at the intermediate depth of $28 \mathrm{~cm}$ (Table 5; RMSE values for 10, 10 38 , and $28-77 \mathrm{~cm}$ are $3,10.2$, and $1.5 \mathrm{mg} \mathrm{L}^{-1}$, respectively). At Turkey Point 89, the modelled and observed values were close at $25 \mathrm{~cm}$ of depth, but the DOC concentration average over the profile down to $100 \mathrm{~cm}$ was overestimated (Table 5). For Guandaushi, DOC measurements from three different stands (natural hardwood, secondary hardwood, and Chinese fir) values were compared with modelled values. The model values for a depth of $15 \mathrm{~cm}$ were closer to observed values for Chinese fir than for natural hardwood or secondary hardwood sites. For $30 \mathrm{~cm}$ of depth, the simulated DOC concentration was substantially lower than the measured DOC averaged over three stands in Guandaushi (Table 5).

Overall, the model was capable of reproducing the seasonality of DOC concentrations for the European sites where 
Table 5. The measured (Obs.) versus the modelled (Mod.) carbon fluxes, SOC concentration, and soil DOC concentration at different soil depths in five study sites.

\begin{tabular}{|c|c|c|c|c|c|c|c|c|c|c|}
\hline \multirow[t]{3}{*}{ Variables } & \multicolumn{6}{|c|}{ Level 1} & \multicolumn{4}{|c|}{ Level 2} \\
\hline & \multicolumn{2}{|c|}{ Brasschaat } & \multicolumn{2}{|c|}{ Carlow } & \multicolumn{2}{|c|}{ Hainich } & \multicolumn{2}{|c|}{ Turkey Point 89} & \multicolumn{2}{|c|}{ Guandaushi } \\
\hline & Obs. & Mod. & Obs. & Mod. & Obs. & Mod. & Obs. & Mod. & Obs. & Mod. \\
\hline \multicolumn{11}{|c|}{ Carbon fluxes $\left(\mathrm{g} \mathrm{C} \mathrm{m}^{-2} \mathrm{yr}^{-1}\right)$ and $\mathrm{SOC}\left(\mathrm{kg} \mathrm{C} \mathrm{m}^{-2}\right)$} \\
\hline GPP & $1173 \pm 92$ & $867 \pm 25$ & 903 & 1165 & $1606 \pm 102$ & $1455 \pm 168$ & $1732 \pm 108$ & $1635 \pm 63$ & - & - \\
\hline NPP & 850 & 596.1 & - & - & $673 \pm 33$ & $833 \pm 153$ & $814 \pm 51$ & $1013 \pm 92$ & - & - \\
\hline Soil res* & $411 \pm 34$ & $625 \pm 54$ & - & - & $883 \pm 206$ & $909 \pm 66$ & $693 \pm 16$ & $1006 \pm 142$ & - & - \\
\hline SOC & 11.47 & 8.01 & 2.3 & 4.17 & 11.75 & 8.63 & 1.85 & 3.39 & - & - \\
\hline \multicolumn{11}{|c|}{ DOC concentration $\left(\mathrm{mg} \mathrm{CL}^{-1}\right)$} \\
\hline $10 \mathrm{~cm}$ & $39 \pm 15$ & $28 \pm 13$ & $7 \pm 3$ & $6 \pm 1$ & $9 \pm 3$ & $9 \pm 2$ & - & - & - & - \\
\hline $15 \mathrm{~cm}$ & - & - & - & - & - & - & - & - & $\begin{array}{r}\text { nh: } 19 \pm 12 \\
\text { sh: } 17 \pm 12 \\
\text { cf: } 8 \pm 15\end{array}$ & $4 \pm 1$ \\
\hline $20 \mathrm{~cm}$ & - & - & - & - & $6 \pm 2$ & $7 \pm 2$ & - & - & - & - \\
\hline $25 \mathrm{~cm}$ & - & - & - & - & - & - & $15 \pm 4.5$ & $16 \pm 4$ & - & - \\
\hline $10-28 \mathrm{~cm}$ & - & - & $13 \pm 4$ & $4 \pm 1$ & - & - & - & - & - & - \\
\hline $30 \mathrm{~cm}$ & - & - & - & - & - & - & - & - & $\begin{array}{r}\text { nh: } 9 \pm 7 \\
\text { sh: } 15 \pm 8 \\
\text { cf: } 7 \pm 17\end{array}$ & $3 \pm 1$ \\
\hline $35 \mathrm{~cm}$ & $29 \pm 2$ & $13 \pm 9$ & - & - & - & - & - & - & - & - \\
\hline $75 \mathrm{~cm}$ & $22 \pm 1$ & $6 \pm 6$ & - & - & - & - & - & - & - & - \\
\hline $28-77 \mathrm{~cm}$ & - & - & $5 \pm 2$ & $5 \pm 0.2$ & - & - & - & - & - & - \\
\hline $100 \mathrm{~cm}$ & - & - & - & - & - & - & $2.2 \pm 0.2$ & $7.9 \pm 2$ & - & - \\
\hline
\end{tabular}

* Soil respiration, nh: natural hardwood; sh: secondary hardwood; cf: Chinese fir.
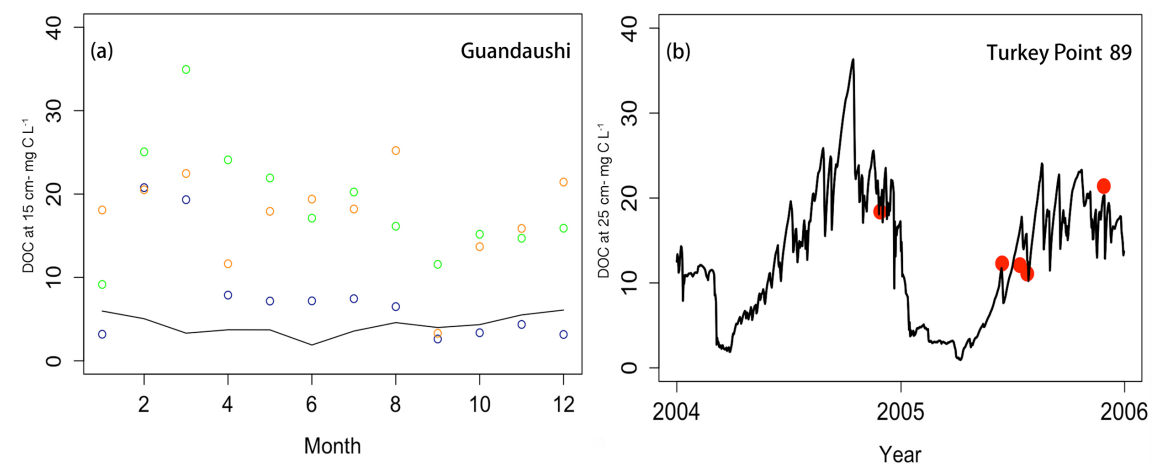

Figure 4. DOC concentration ( $\mathrm{mg} \mathrm{CL}^{-1}$ ) for (a) Guandaushi at $15 \mathrm{~cm}$ measured (black circle: Chinese fir, green circle: natural hardwood, orange circle: secondary wood) and simulated (black lines) and for (b) Turkey Point 89 at $25 \mathrm{~cm}$ measured (red dots) and simulated (black lines). Results for other depths are given in Fig. S2.

long-term observation data are available (Fig. 5). However, at Brasschaat the simulated DOC peaked from April-July, while observed DOC peaked from July-September.

We also examined the hydrology of the model and its interaction with DOC concentration and leaching (e.g. Hainich Fig. 6; other sites are plotted in Fig. S3 in the Supplement). It can be seen for the period 2005-2014 that during heavy precipitation, high run-off was produced, which caused the higher leaching, and the consequence was a drop in the DOC concentration in $3 \mathrm{~m}$ of soil.

\subsection{Sensitivity tests}

Sensitivity to model parameters was tested on the three European sites where a representative time series of observed DOC concentrations was available (e.g. Hainich; $10 \mathrm{~cm}$, Fig. 7). The results indicate that among all the parameters in all three sites, the model shows the highest sensitivity to SOC vertical profile controlled by parameter $z_{0}$ (Eq. 1) and the changing of SOC decomposition rate with soil depth controlled by parameter $\tau_{z}$ (Eq. 4; $p$ values $<0.05$, Table S6). Among the DOC controlling parameters, the model shows 

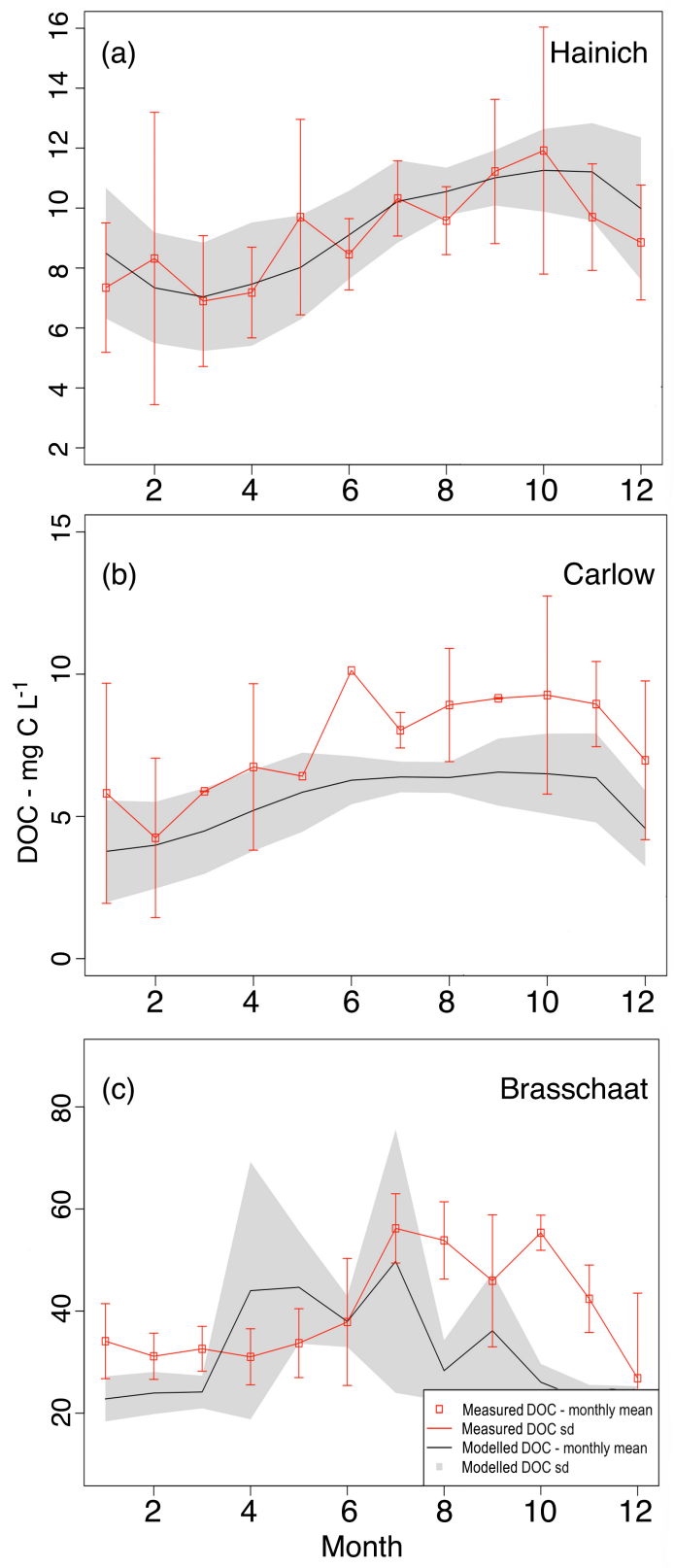

Figure 5. (a) Monthly DOC $\left(\mathrm{mg} \mathrm{C} \mathrm{L}^{-1}\right)$ at $10 \mathrm{~cm}$ in Level 1 sites modelled (black line: mean, grey line: standard deviation) versus measured (red square: mean, red line: standard deviation) for the studied period: (a) Hainich average from 2005 to 2014, (b) Carlow average from 2006 to 2008, (c) Brasschaat average from 2006 to 2010. Results for other depths are given in Fig. S6.

the highest sensitivity to the basal decomposition rate of re-

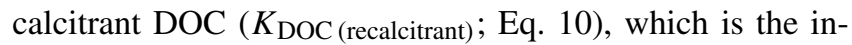
verse of the residence time of DOC in the recalcitrant pool.

The sensitivity of the model to each of these parameters was different at each site. For Hainich, the highest sensitivity was assigned to $\tau_{z}$. Here, a change in $\tau_{z}$ by $50 \%$ leads to a $36 \%$ change in the mean DOC within $3 \mathrm{~m}$, while a
$50 \%$ change in $K_{\mathrm{DOC} \text { (recalcitrant) }}$ leads to a $29 \%$ change and global $z_{0}$ leads to a $25 \%$ change in simulated DOC concentrations (Fig. 8a). The closest value for the mean DOC in $10 \mathrm{~cm}$ in Hainich $\left(8.8 \mathrm{mg} \mathrm{L}^{-1}\right)$ to the measurement was produced by the default set $\left(8.9 \mathrm{mg} \mathrm{L}^{-1}\right)$, while the highest value for DOC was reached with the $50 \%$ increase in $\tau_{z}\left(12.7 \mathrm{mg} \mathrm{L}^{-1}\right)$ and the lowest DOC value was produced with a $50 \%$ decrease in $\tau_{z}\left(4.7 \mathrm{mg} \mathrm{L}^{-1}\right)$. In contrast to that, at a depth of $20 \mathrm{~cm}$, the closest value to the mean of measured DOC $\left(5.6 \mathrm{mg} \mathrm{L}^{-1}\right)$ was produced by a $50 \%$ decrease in $K_{\mathrm{DOC} \text { (recalcitrant) }}\left(4.9 \mathrm{mg} \mathrm{L}^{-1}\right.$; Fig. $\left.9 \mathrm{a}\right)$.

In Brasschaat, the highest sensitivity was to $z_{0}$, closely fol-

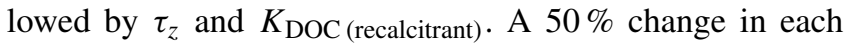
of these parameters led to a 36-40\% change in DOC concentration over the $3 \mathrm{~m}$ soil profile (Fig. $8 \mathrm{~b}$ ). At $10 \mathrm{~cm}$, the closest value to the measurement mean $\left(39.4 \mathrm{mg} \mathrm{L}^{-1}\right)$ was produced by a $50 \%$ increase in $\tau_{z}\left(39.2 \mathrm{mg} \mathrm{L}^{-1}\right)$. At $35 \mathrm{~cm}$ of depth, the closest value to the mean measurement $\left(29.3 \mathrm{mg} \mathrm{L}^{-1}\right)$ was calculated by a $50 \%$ increase in $K_{\text {DOC (recalcitrant) }}\left(16.2 \mathrm{mg} \mathrm{L}^{-1}\right)$, which was also the highest simulated value. At $75 \mathrm{~cm}$, the closest value to the mean of the DOC measurement $\left(22.0 \mathrm{mg} \mathrm{L}^{-1}\right)$ was produced by a $50 \%$ increase in $K_{\text {DOC (recalcitrant) }}\left(8.1 \mathrm{mg} \mathrm{L}^{-1}\right)$ as it was the highest of the simulated values (Fig. 9b).

For Carlow, the most sensitive parameters were $\tau_{z}$ and $K_{\text {DOC (recalcitrant) }}$. A $50 \%$ change in those parameters leads to a 31.5 and $27.4 \%$ increase in simulated DOC. In contrast to the other sites, global $z_{0}$ leads to a low but still significant positive change of $6.5 \%$ in simulated DOC within $3 \mathrm{~m}$ of soil ( $p$ value $<0.05$; Table S6, Fig. $8 \mathrm{c}$ ). In $10 \mathrm{~cm}$, the closest modelled value to the mean measurement $\left(5.7 \mathrm{mg} \mathrm{L}^{-1}\right)$ was produced by the default parameter set $\left(5.8 \mathrm{mg} \mathrm{L}^{-1}\right)$. Between 10 and $28 \mathrm{~cm}$ all the parameter sets underrepresented the DOC concentration mean measurement $\left(13.1 \mathrm{mg} \mathrm{L}^{-1}\right)$ and the closest and highest value was produced by a $50 \%$ increase in $\tau_{z}\left(3.8 \mathrm{mg} \mathrm{L}^{-1}\right)$. For 28 to $77 \mathrm{~cm}$, the closest value to the measurement $\left(4.8 \mathrm{mg} \mathrm{L}^{-1}\right)$ was calculated by increasing $\tau_{z}$ by $50 \%$ ( $4.5 \mathrm{mg} \mathrm{L}^{-1}$; Fig. 9).

\section{Discussion}

\subsection{Measurements versus model simulations}

Overall, JULES-DOCM reproduced the range of GPP for most of our sites to an acceptable degree. At some sites, due to overestimated or underestimated autotrophic respiration, the NPP and total respiration values were slightly different than measurements. Consequently, the modelled carbon stocks were different from the measurements in most of the sites, yet were capable of representing the general patterns that were observed in the measurements.

In Brasschaat, the modelled SOC was lower than the measurements, which could be due to the underestimated NPP (Table 5) and, as a consequence, the underestimated litter in- 

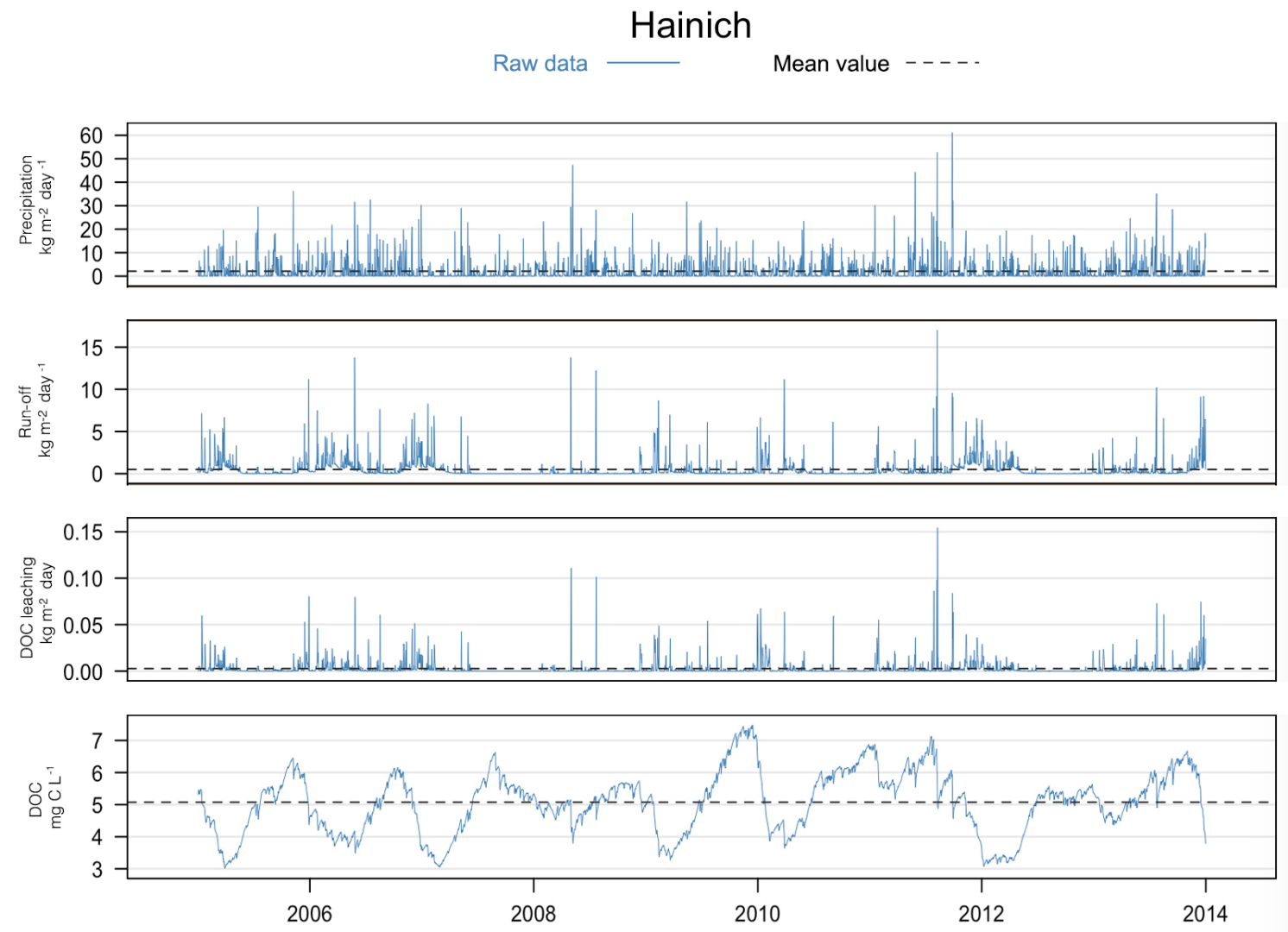

Figure 6. Observed precipitation, simulated run-off, DOC leaching, and DOC concentration in Hainich from 2006 to 2013 indicating the relation between the averaged DOC concentrations in $3 \mathrm{~m}$ of soil with leaching as a result of run-off that follows large precipitation events.

put, but also due to the overestimated soil respiration and SOC decomposition rates. The underestimation of SOC as a source of DOC led to a general underestimation of DOC. Nevertheless, the decrease in relative DOC concentration through the soil is consistent with the observations.

In Hainich, a slightly overestimated NPP partly counterbalanced the overestimated soil respiration. Nevertheless, the SOC concentration simulated down to $60 \mathrm{~cm}$ was lower than the measurement at this depth. As we did not have observations of SOC down to $3 \mathrm{~m}$, we cannot definitively say if the simulated total SOC stock $\left(13.7 \mathrm{~kg} \mathrm{C} \mathrm{m}^{-2}\right)$ over the whole soil column is close to the reality or not. Some of the controlling parameters like DOC basal decomposition rates are kept constant over the soil profile in our simulation, while they are maybe not constant with depth in the real world, perhaps due to priming effects (Guenet et al., 2010). That could explain why at Hainich the simulated and observed DOC concentrations are very close at $10 \mathrm{~cm}$ of depth, while they differ more at $20 \mathrm{~cm}$ of depth.

In Carlow, the slight overestimation of GPP led to the overestimated SOC concentrations down to $50 \mathrm{~cm}$, whilst again we cannot say with certainty that the whole SOC stock is overestimated, as the SOC stock has not been measured down to $3 \mathrm{~m}$. Some sources suggest that the $\mathrm{SOC}$ in Carlow grassland could be higher than the reported value in our reference if we calculate the $\mathrm{C}$ in soil based on the fraction of loss of ignition (LOI; Walmsley, 2009; Hoogsteen et al., 2015). As Carlow is our only grassland biome site, additional data from different study sites would be valuable to achieve a more representative parameterization of soil carbon processes under grassland. One of the parameters to be optimized for such sites could be CUE, which has a strong impact on the stocks and fluxes. Also, since the measured values for NPP or soil respiration for this site were not available to us, we were unable to assess whether we overestimated or underestimated these fluxes and if this could have potentially biased our SOC stock simulations. DOC measurements were provided from two plots which were placed on different terrain positions. The measurements from plot $2(150 \mathrm{~m}$ in the south-westerly direction from plot 1) at 10 to $28 \mathrm{~cm}$ of depth had a higher DOC concentration than plot 1 at $10 \mathrm{~cm}$ (Walmsley, 2009). This could be the result of small-scale variations related to terrain position, which can be related to different soil moisture regimes and the lateral import of DOC. It is not possible to represent such small-scale variation in global models like JULES-DOCM. 

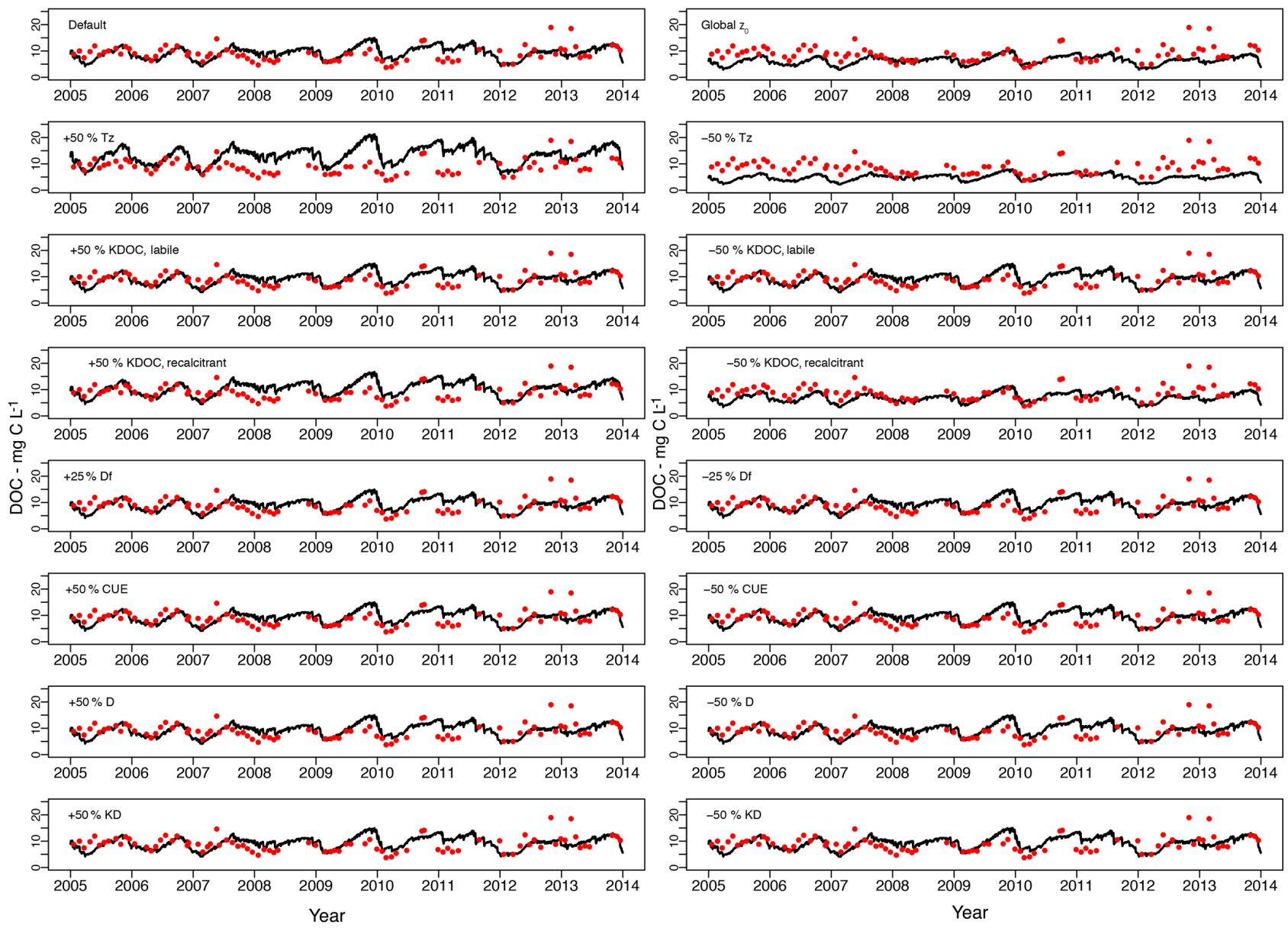

Figure 7. DOC concentration ( $\mathrm{mg} \mathrm{C} \mathrm{L}^{-1}$ ) simulated with sensitivity parameter sets (black line) versus measured (red dot) at $10 \mathrm{~cm}$ of depth in Hainich for the period 2004-2013. Parameter set descriptions and values are given in Table 1. Results for other sites are given in Fig. S1.

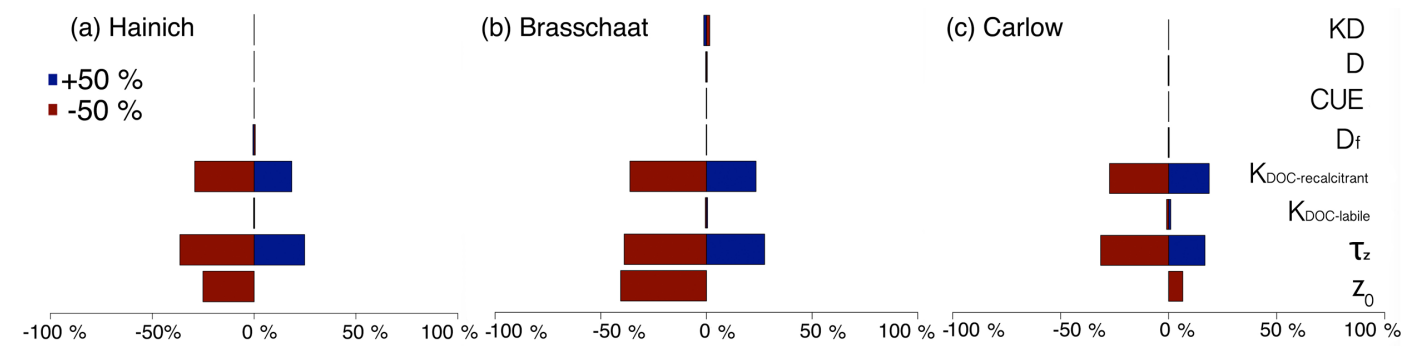

Figure 8. Relative change in simulated DOC $(\%)$ for a $+50 \%$ (blue) and $-50 \%$ (red) change in each parameter for Level 1 sites: (a) Hainich, (b) Brasschaat, and (c) Carlow. Values are given in Table S5.

At Turkey Point 89, the simulated GPP is close to the observations, while NPP is slightly overestimated. The simulated soil respiration and decomposition rates are higher than observed values. The overestimated SOC concentration in the topsoil could be the result of an overestimated depth gradient in SOC concentration, which in our simulations is derived from global data (Jobbágy and Jackson, 2000). Also, we simulated the steady-state SOC profile for forest vegetation, whereas the forest stand at the site is relatively young and succeeded agricultural land use in 1989; thus, the SOC profile is likely not representative of a forest site. The overestimated DOC concentration for $100 \mathrm{~cm}$ of depth may be due to this change in land use, which was not taken into account during simulations as providing more $\mathrm{C}$ input for DOC production. At this site, the observed higher soil moisture in the deeper profile could indicate a potentially high advection of DOC to the lower layers (Peichl et al., 2010a). This could be 

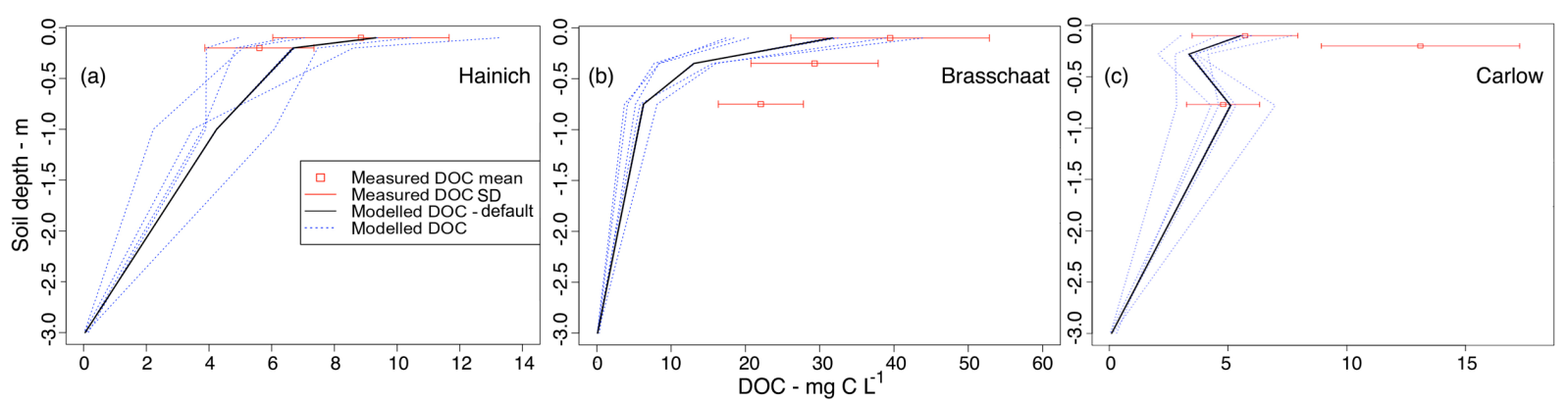

Figure 9. DOC concentration $\left(\mathrm{mg} \mathrm{C} \mathrm{L}^{-1}\right)$ in $3 \mathrm{~m}$ of soil depth at Level 1 sites modelled (black line: default parameter set; blue dashed line: sensitivity test parameter set) versus measured (red square: mean; red line: standard deviation) for (a) Hainich, (b) Brasschaat, and (c) Carlow. Plot of each parameter in $3 \mathrm{~m}$ of soil depth in Fig. S5.

another reason for the lower DOC in $100 \mathrm{~cm}$ from the measured compared to the modelled results.

In Guandaushi, due to the lack of SOC or vegetation carbon flux measurements from the site, we have no information on SOC concentrations and stocks. The lower values of DOC from our model compared to the measurements could be due to the high temporal variability of observed concentrations (large standard deviation for all the depths from the three stands). It could also be due to the high value of DOC input from rainfall, which is not represented in JULES-DOCM (Liu and Sheu, 2003). Recent studies have indicated that including this flux in models can have a significant impact on the DOC in soil (Lauerwald et al., 2017).

As there are no measurements of lateral leaching of DOC from soil to the river, our evaluation of this flux is based on the simulated DOC concentration and run-off. Hence as the simulated hydrology of the JULES model has been evaluated previously (Gedney and Cox, 2003; Clark and Gedney, 2008), in this study we assume that we will get robust estimates of DOC leaching by multiplying the simulated concentration by run-off as long as simulated DOC concentrations can be validated.

Overall, aside from overestimation or underestimation of DOC at some sites, the model was capable of representing the trend of DOC concentration at different depths compared to the measurements at all the sites.

\subsection{Sensitivity analysis}

The sensitivity tests indicate that the parameters controlling SOC concentrations in the soil profile $\left(Z_{0}\right.$ and $\left.\tau_{z}\right)$ and the recalcitrant DOC residence time $\left(K_{\mathrm{DOC} \text { (recalcitrant) }}\right)$ have the most significant effect on soil DOC concentration, which indicates the importance of factors controlling DOC sources. Nevertheless, DOC-related model parameters such as the basal DOC decomposition rate are constant over different depths, which could be the reason for the difference between the modelled and measured values, especially in the deeper soil layers. Hence, it is important to introduce a depthdependence decay rate for these parameters.
One limitation in our simulation is that we use a single, calibrated value for recalcitrant DOC residence time, which is the most sensitive DOC controlling parameter. It has been shown that this parameter can vary with the biodegradability of SOC and litter under different PFTs and at different sites (Kalbitz et al., 2003; Turgeon, 2008). However, more detailed data for different biomes are needed for calibrating different residence times for different PFTs. We note that our sensitivity analysis, by changing one parameter at a time, does not investigate the potential interactions among different parameters.

\section{Conclusion}

Applying a carbon cycle model that integrates the whole continuum from land to ocean to atmosphere provides a better understanding of the Earth's carbon cycle and makes more reliable future projections. In this study, we presented DOCrelated processes in JULES, JULES-DOCM, which includes the DOC produced in the soil down to $3 \mathrm{~m}$ and its subsequent fate including its decomposition and release as $\mathrm{CO}_{2}$ to the atmosphere and its export to the river network via leaching in different ecosystems. Results show that the model is capable of representing the DOC stocks, processes, and export to the riverine systems from different ecosystems. In future, our developments in the representation of DOC leaching will lead to a model approach integrating terrestrial and aquatic $\mathrm{C}$ cycling. However, more field data are still required to improve the model parameterization and performance.

Code availability. The code written for this version of JULES can be found at https://code.metoffice.gov.uk/svn/jules/main/branches/ $\mathrm{dev} /$ mahdinakhavali/vn4.4JULESDOCM/ (registration required).

The Supplement related to this article is available online at https://doi.org/10.5194/gmd-11-593-2018-supplement. 
Competing interests. The authors declare that they have no conflict of interest.

Acknowledgements. The research leading to these results received funding from the European Union's Horizon 2020 research and innovation programme under Marie Sklodowska-Curie grant agreement no. 643052 (C-CASCADES project). We want to thank Altaf Arain, Tim Moore, and Gerd Glexiner for providing the DOC measurements. Ronny Lauerwald received funding from the European Union's Horizon 2020 research and innovation programme under grant agreement no. 703813 for the Marie Sklodowska-Curie European Individual Fellowship "C-Leak". Jing Tang is financed by a Marie Sklodowska-Curie Action Individual Fellowship (MABVOC: 707187) and supported by the Danish National Research Foundation (CENPERM DNRF100). Marta Camino-Serrano acknowledges funding from the European Research Council Synergy grant ERC-2013-SyG-610028 IMBALANCE-P.

Edited by: Christoph Müller

Reviewed by: two anonymous referees

\section{References}

Aguilar, L. and Thibodeaux, L. J.: Kinetics of peat soil dissolved organic carbon release from bed sediment to water. Part 1. Laboratory simulation, Chemosphere, 58, 1309-1318, 2005.

Aitkenhead, J. A. and Mcdowell, W. H.: Soil C:N ratio as a predictor of annual riverine DOC flux at local and global scales, Global Biogeochem Cy., 14, 127-138, 2000.

Battin, T. J., Luyssaert, S., Kaplan, L. A., Aufdenkampe, A. K., Richter, A., and Tranvik, L. J.: The boundless carbon cycle, Nat. Geosci., 2, 598-600, https://doi.org/10.1038/ngeo618, 2009.

Best, M. J., Pryor, M., Clark, D. B., Rooney, G. G., Essery, R. L. H., Ménard, C. B., Edwards, J. M., Hendry, M. A., Porson, A., Gedney, N., Mercado, L. M., Sitch, S., Blyth, E., Boucher, O., Cox, P. M., Grimmond, C. S. B., and Harding, R. J.: The Joint UK Land Environment Simulator (JULES), model description Part 1: Energy and water fluxes, Geosci. Model Dev., 4, 677-699, https://doi.org/10.5194/gmd-4-677-2011, 2011.

Boyer, J. N. and Groffman, P. M.: Bioavailability of water extractable organic carbon fractions in forest and agricultural soil profiles, Soil Biol. Biochem., 28, 783-790, 1996.

Braakhekke, M. C., Wutzler, T., Beer, C., Kattge, J., Schrumpf, M., Ahrens, B., Schöning, I., Hoosbeek, M. R., Kruijt, B., Kabat, P., and Reichstein, M.: Modeling the vertical soil organic matter profile using Bayesian parameter estimation, Biogeosciences, 10, 399-420, https://doi.org/10.5194/bg-10-399-2013, 2013.

Burke, E. J., Chadburn, S. E., and Ekici, A.: A vertical representation of soil carbon in the JULES land surface scheme (vn4.3_permafrost) with a focus on permafrost regions, Geosci. Model Dev., 10, 959-975, https://doi.org/10.5194/gmd-10-9592017, 2017.

Clark, D. B. and Gedney, N.: Representing the effects of subgrid variability of soil moisture on runoff generation in a land surface model, J. Geophys. Res., 113, D10111, https://doi.org/10.1029/2007JD008940, 2008.
Clark, D. B., Mercado, L. M., Sitch, S., Jones, C. D., Gedney, N., Best, M. J., Pryor, M., Rooney, G. G., Essery, R. L. H., Blyth, E., Boucher, O., Harding, R. J., Huntingford, C., and Cox, P. M.: The Joint UK Land Environment Simulator (JULES), model description - Part 2: Carbon fluxes and vegetation dynamics, Geosci. Model Dev., 4, 701-722, https://doi.org/10.5194/gmd-4701-2011, 2011.

Cole, J. J., Prairie, Y. T., Caraco, N. F., McDowell, W. H., Tranvik, L. J., Striegl, R. G., Duarte, C. M., Kortelainen, P., Downing, J. A., Middelburg, J. J., and Melack, J.: Plumbing the global carbon cycle: Integrating inland waters into the terrestrial carbon budget, Ecosystems, 10, 171-184, 2007.

Coleman, K. and Jenkinson, D.: RothC - A Model for the Turnover of Carbon in Soil, Model description and windows user guide, Evaluation of Soil Organic Matter Models: Using Existing LongTerm Datasets, I, 237-246, 2014.

Gedney, N. and Cox, P. M.: The Sensitivity of Global Climate Model Simulations to the Representation of Soil Moisture Heterogeneity, J. Hydrometeor., 4, 1265-1275, 2003.

Gielen, B., Verbeeck, H., Neirynck, J., Sampson, D. A., Vermeiren, F., and Janssens, I. A.: Decadal water balance of a temperate Scots pine forest (Pinus sylvestris L.) based on measurements and modelling, Biogeosciences, 7, 1247-1261, https://doi.org/10.5194/bg-7-1247-2010, 2010.

Gielen, B., Neirynck, J., Luyssaert, S., and Janssens, I. A.: The importance of dissolved organic carbon fluxes for the carbon balance of a temperate Scots pine forest, Agr. Forest Meteorol., 151, 270-278, 2011.

Guenet, B., Danger, M., Abbadie, L., and Lacroix, G.: Priming effect: Bridging the gap between terrestrial and aquatic ecology, Ecology, 91, 2850-2861, 2010.

Harper, A. B., Cox, P. M., Friedlingstein, P., Wiltshire, A. J., Jones, C. D., Sitch, S., Mercado, L. M., Groenendijk, M., Robertson, E., Kattge, J., Bönisch, G., Atkin, O. K., Bahn, M., Cornelissen, J., Niinemets, Ü., Onipchenko, V., Peñuelas, J., Poorter, L., Reich, P. B., Soudzilovskaia, N. A., and Bodegom, P. V.: Improved representation of plant functional types and physiology in the Joint UK Land Environment Simulator (JULES v4.2) using plant trait information, Geosci. Model Dev., 9, 2415-2440, https://doi.org/10.5194/gmd-9-2415-2016, 2016.

Hoogsteen, M. J. J., Lantinga, E. A., Bakker, E. J., Groot, J. C. J., and Tittonell, P. A.: Estimating soil organic carbon through loss on ignition: Effects of ignition conditions and structural water loss, Eur. J. Soil Sci., 66, 320-328, 2015.

Jackson, R. B., Banner, J. L., Jobbágy, E. G., Pockman, W. T., and Wall, D. H.: Ecosystem carbon loss with woody plant invasion of grasslands, Nature, 418, 623-626, https://doi.org/10.1038/nature00910, 2002.

Janssens, I. A., Sampson, D. A., Cermak, J., Meiresonne, L., Riguzzi, F., Overloop, S., and Ceulemans, R.: Above- and belowground phytomass and carbon storage in a Belgian Scots pine stand, Ann. For. Sci., 56, 81-90, 1999.

Janssens, I. A., Freibauer, A., Ciais, P., Smith, P., Nabuurs, G.-J., Folberth, G., Schlamadinger, B., Hutjes, R. W. A., Ceulemans R.,, Schulze, E.-D., Valentini, R., and Dolman, A. J.: Europe ' $\mathrm{s}$ Terrestrial Biosphere Anthropogenic $\mathrm{CO}_{2}$ Emissions, Science, 300, 1538-1542, 2003. 
Jenkinson, D. S. and Coleman, K.: The turnover of organic carbon in subsoils. Part 2. Modelling carbon turnover, Eur. J. Soil Sci., 59, 400-413, 2008.

Jenkinson, D. S., Andrew, S. P. S., Lynch, J. M., Goss, M. J., and Tinker, P. B.: The turnover of organic carbon and nitrogen in soil, Philos. T. Roy. Soc. B, 329, 361-368, 1990.

Jobbágy, E. G. and Jackson, R. B.: The vertical distribution of soil organic carbon and its relation to climate and vegetation, Ecol. Appl., 10, 423-436, 2000.

Kalbitz, K., Solinger, S., Park, J.-H., Michalzik, B., and Matzner, E.: Controls on the Dynamics of Dissolved Organic Matter in Soils A Review, Soil Sci., 165, 277-304, 2000.

Kalbitz, K., Schmerwitz, J., Schwesig, D., and Matzner, E.: Biodegradation of soil-derived dissolved organic matter as related to its properties, Geoderma, 113, 273-291, 2003.

Khomutova, T. E., Shirshova, L. T., Tinz, S, Rolland, W., and Richter, J.: Mobilization of DOC from sandy loamy soils under different land use (Lower Saxony, Germany), Plant Soil, 219, 1319, 2000.

Kicklighter, D. W., Hayes, D. J., McClelland, J. W., Peterson, B. J., McGuire, A. D., and Melillo, J. M.: Insights and issues with simulating terrestrial DOC loading of Arctic river networks, Ecol. Appl., 23, 1817-1836, 2013.

Kindler, R., Siemens, J., Kaiser, K., Walmsley, D. C., Bernhofer, C., Buchmann, N., Cellier, P., Eugster, W., Gleixner, G., Grunwald, T., Heim, A., Ibrom, A., Jones, S. K., Jones, M., Klumpp, K., Kutsch, W., Larsen, K. S., Lehuger, S., Loubet, B., Mckenzie, R., Moors, E., Osborne, B., Pilegaard, K., Rebmann, C., Saunders, M., Schmidt, M. W. I., Schrumpf, M., Seyfferth, J., Skiba, U., Soussana, J.-F., Sutton, M. A., Tefs, C., Vowinckel, B., Zeeman, M. J., and Kaupenjohann, M. Dissolved carbon leaching from soil is a crucial component of the net ecosystem carbon balance, Glob. Change Biol., 17, 1167-1185, https://doi.org/10.1111/j.1365-2486.2010.02282.x, 2011.

Koven, C. D., Riley, W. J., Subin, Z. M., Tang, J. Y., Torn, M. S., Collins, W. D., Bonan, G. B., Lawrence, D. M., and Swenson, S. C.: The effect of vertically resolved soil biogeochemistry and alternate soil $\mathrm{C}$ and $\mathrm{N}$ models on C dynamics of CLM4, Biogeosciences, 10, 7109-7131, https://doi.org/10.5194/bg-107109-2013, 2013.

Kutsch, W. L., Persson, T., Schrumpf, M., Moyano, F. E., Mund, M., Andersson, S., and Schulze, E.-D.: Heterotrophic soil respiration and soil carbon dynamics in the deciduous Hainich forest obtained by three approaches, Biogeochemistry, 100, 167-183, https://doi.org/10.1007/s10533-010-9414-9, 2010.

Langerwisch, F., Walz, A., Rammig, A., Tietjen, B., Thonicke, K., and Cramer, W.: Deforestation in Amazonia impacts riverine carbon dynamics, Earth Syst. Dynam., 7, 953-968, https://doi.org/10.5194/esd-7-953-2016, 2016.

Lauerwald, R., Regnier, P., Camino-Serrano, M., Guenet, B., Guimberteau, M., Ducharne, A., Polcher, J., and Ciais, P.: ORCHILEAK (revision 3875): a new model branch to simulate carbon transfers along the terrestrial-aquatic continuum of the Amazon basin, Geosci. Model Dev., 10, 3821-3859, https://doi.org/10.5194/gmd-10-3821-2017, 2017.

Le Quéré, C., Moriarty, R., Andrew, R. M., Canadell, J. G., Sitch, S., Korsbakken, J. I., Friedlingstein, P., Peters, G. P., Andres, R. J., Boden, T. A., Houghton, R. A., House, J. I., Keeling, R. F., Tans, P., Arneth, A., Bakker, D. C. E., Barbero, L., Bopp, L., Chang,
J., Chevallier, F., Chini, L. P., Ciais, P., Fader, M., Feely, R. A., Gkritzalis, T., Harris, I., Hauck, J., Ilyina, T., Jain, A. K., Kato, E., Kitidis, V., Klein Goldewijk, K., Koven, C., Landschützer, P., Lauvset, S. K., Lefèvre, N., Lenton, A., Lima, I. D., Metzl, N., Millero, F., Munro, D. R., Murata, A., Nabel, J. E. M. S., Nakaoka, S., Nojiri, Y., O’Brien, K., Olsen, A., Ono, T., Pérez, F. F., Pfeil, B., Pierrot, D., Poulter, B., Rehder, G., Rödenbeck, C., Saito, S., Schuster, U., Schwinger, J., Séférian, R., Steinhoff, T., Stocker, B. D., Sutton, A. J., Takahashi, T., Tilbrook, B., van der Laan-Luijkx, I. T., van der Werf, G. R., van Heuven, S., Vandemark, D., Viovy, N., Wiltshire, A., Zaehle, S., and Zeng, N.: Global Carbon Budget 2015, Earth Syst. Sci. Data, 7, 349-396, https://doi.org/10.5194/essd-7-349-2015, 2015.

Liu, C. P. and Sheu, B. H.: Dissolved organic carbon in precipitation, throughfall, stemflow, soil solution, and stream water at the Guandaushi subtropical forest in Taiwan, Forest Ecol. Manag., 172, 315-325, 2003.

Manzoni, S., Taylor, P., Richter, A., Porporato, A., and Ågren, G. I.: Environmental and stoichiometric controls on microbial carbonuse efficiency in soils, New Phytol., 196, 79-91, 2012.

Marschner, H.: Mineral Nutrition of Higher Plants, available at: https://books.google.co.uk/books?id=phnp-H1XeBkC (last access: 8 March 2017), Academic Press, Gulf Professional Publishing-Germany, 1995.

Meybeck, M.: Riverine transport of atmospheric carbon: Sources, global typology and budget, Water Air Soil Poll., 70, 443-463, 1993.

Michalzik, B., Tipping, E., Mulder, J., Gallardo Lancho, J. F., Matzner, E., Bryant, C. L., Clarke, N., Lofts, S., and Vicente Esteban, M. A.: Modelling the production and transport of Dissolved Organic Carbon in forest soils, Biogeochemistry, 66, 241264, https://doi.org/10.1023/B:BIOG.0000005329.68861.27, 2003.

Moore, T. R., de Souza, W., and Koprivnjak, J.-F.: Controls on the sorption of dissolved organic carbon by soils, Soil Sci., 154, 120129, 1992.

Mund, M. Kutsch, W. L., Wirth, C., Kahl, T., Knohl, A., Skomarkova, M. V., and Schulze, E.-D.: The influence of climate and fructification on the inter-annual variability of stem growth and net primary productivity in an old-growth, mixed beech forest, Tree Physiol., 30, 689-704, 2010.

Nachtergaele, F., Nachtergaele, F., Van Velthuizen, H., Verelst, L., Batjes, N., Dijkshoorn, K., Van Engelen, V., Fischer, G., Jones, A., Montanarella, L., Petri, M., Prieler, S., Shi, X., Teixeira, E., and Wiberg, D.: The Harmonized World Soil Database, Proceedings of the 19th World Congress of Soil Science, Soil Solutions for a Changing World, Brisbane, Australia, 1-6 August 2010, 34-37, 2010.

Neff, J. C. and Asner, G. P.: Dissolved organic carbon in terrestrial ecosystems: Synthesis and a model, Ecosystems, 4, 29-48, 2001.

Olson, J. S.: Energy Storage and the Balance of Producers and Decomposers in Ecological Systems, Ecology, 44, 322-331, 1963.

Ota, M., Nagai, H., and Koarashi, J.: Root and dissolved organic carbon controls on subsurface soil carbon dynamics: A model approach, J. Geophys. Res.-Biogeosc., 118, 1646-1659, 2013.

Parton, W. J., Schimel, D. S., and Ojima, C. V. C. D. S.: Analysis of Factors Controlling Soil Organic Matter Levels in Great Plains Grasslands, Soil Sci. Soc. Am. J., 51, 1173-1179, 1987. 
Peichl, M. and Arain, M. A.: Above- and belowground ecosystem biomass and carbon pools in an age-sequence of temperate pine plantation forests, Agr. Forest Meteorol., 140, 51-63, 2006.

Peichl, M., Moore, T. R., Arain, M. A., Dalva, M., Brodkey, D., and McLaren, J.: Concentrations and fluxes of dissolved organic carbon in an age-sequence of white pine forests in Southern Ontario, Canada, Biogeochemistry, 86, 1-17, 2007.

Peichl, M., Arain, M. A., and Brodeur, J. J.: Age effects on carbon fluxes in temperate pine forests, Agr. Forest Meteorol., 150, 1090-1101, https://doi.org/10.1016/j.agrformet.2010.04.008, 2010a.

Peichl, M., Brodeur, J. J., Khomik, M., and Arain, M. A.: Biometric and eddy-covariance based estimates of carbon fluxes in an age-sequence of temperate pine forests, Agr. Forest Meteorol., 150, 952-965, https://doi.org/10.1016/j.agrformet.2010.03.002, 2010b.

Presant, E. W. and Acton, C. J.: The soils of the regional municipality of Haldimand-Norfolk, Land Resource Research Institute, Research Branch, Agriculture Canada, Guelph, Ontario, Report No. 57, p. 100, 1984.

Regnier, P., Friedlingstein, P., Ciais, P., Mackenzie, F. T., Gruber, N., Janssens, I. A., Laruelle, G. G., Lauerwald, R., Luyssaert, S., Andersson, A. J., Arndt, S., Arnosti, C., Borges, A. V., Dale, A. W., Gallego-Sala, A., Goddéris, Y., Goossens, N., Hartmann, J., Heinze, C., Ilyina, T., Joos, F., LaRowe, D. E., Leifeld, J., Meysman, F. J. R., Munhoven, G., Raymond, P. A., Spahni, R., Suntharalingam, P., and Thullner, M.: Anthropogenic perturbation of the carbon fluxes from land to ocean, Nat. Geosci., 6, 597-607, https://doi.org/10.1038/ngeo1830, 2013.

Rumpel, C. and Kögel-Knabner, I.: Deep soil organic matter-a key but poorly understood component of terrestrial C cycle, Plant Soil, 338,pp.143-158, 2011.

Schelker, J., Grabs, T., Bishop, K., and Laudon, H.: Drivers of increased organic carbon concentrations in stream water following forest disturbance: Separating effects of changes in flow pathways and soil warming, J. Geophys. Res.-Biogeosci., 118, 18141827, 2013.

Schrumpf, M., Schulze, E. D., Kaiser, K., and Schumacher, J.: How accurately can soil organic carbon stocks and stock changes be quantified by soil inventories?, Biogeosciences, 8, 1193-1212, https://doi.org/10.5194/bg-8-1193-2011, 2011

Siemens, J.: The European Carbon Budget: A Gap, Science, 302, 1681, https://doi.org/10.1126/science.302.5651.1681a, 2003.

Sitch, S., Friedlingstein, P., Gruber, N., Jones, S. D., MurrayTortarolo, G., Ahlström, A., Doney, S. C., Graven, H., Heinze, C., Huntingford, C., Levis, S., Levy, P. E., Lomas, M., Poulter, B., Viovy, N., Zaehle, S., Zeng, N., Arneth, A., Bonan, G., Bopp, L., Canadell, J. G., Chevallier, F., Ciais, P., Ellis, R., Gloor, M., Peylin, P., Piao, S. L., Le Quéré, C., Smith, B., Zhu, Z., and Myneni, R.: Recent trends and drivers of regional sources and sinks of carbon dioxide, Biogeosciences, 12, 653679, https://doi.org/10.5194/bg-12-653-2015, 2015.
Smith, J., Gottschalk, P., Bellarby, J., Chapman, S., Lilly, A., Towers, W., Bell, J., Coleman, K., Nayak, D., Richards, M., Hillier, J., Flynn, H., Wattenbach, M., Aitkenhead, M., Yeluripurti, J., Farmer, J., Milne, R., Thomson, A., Evans, C., and Smith, P.: Estimating changes in national soil carbon stocks using ECOSSE - a new model that includes upland organic soils. Part II. Application in Scotland, Clim. Res., 45, 193-205, https://doi.org/10.3354/cr00902, 2010.

Smith, P., Smith, J., Flynn, H., Killham, K., Rangel-Castro, I., Foereid, B., Aitkenhead, M., Chapman, S., Towers, W., Bell, J., Lumsdon, D., Milne, R., Thomson, A., Simmons, I., Skiba, U., Reynolds, B., Evans, C., Frogbrook, Z., Bradley, I., Whitmore, A., and Falloon, P.: Model to Estimate Carbon in Organic Soils - Sequestration and Emissions (ECOSSE), Carbon, 44, 1-73, 2010.

Soil Classification Working Group: The Canadian System of Soil Classification, 3rd Edn., NRC Research Press, Agriculture and Agri-Food Canada Publication 1646, 187 pp., 1998.

Thibodeaux, L. J. and Aguilar, L.: Kinetics of peat soil dissolved organic carbon release to surface water. Part 2 . A chemodynamic process model, Chemosphere, 60, 1190-1196, 2005.

Turgeon, J.: Production and biodegradation of dissolved carbon, nitrogen and phosphorus from Canadian forest floors, McGill University, 2008.

Van den berg, L. J. L., Shotbolt, L., Ashmore, M. R.: Dissolved organic carbon (DOC) concentrations in UK soils and the influence of soil, vegetation type and seasonality, Sci. Total Environ., 427428, 269-276, https://doi.org/10.1016/j.scitotenv.2012.03.069, 2012.

Walmsley, D. C.: Quantifying Dissolved Carbon and Nitrogen Losses from Soils Subjected to Different Land-use and Management Practices, University College Dublin, available at: https: //books.google.fr/books?id=HCz2ZwEACAAJ (last access: 12 April 2017), 2009.

Walmsley, D. C., Siemens, J., Kindler, R., Kirwan, L., Kaiser, K., Saunders, M., Kaupenjohann, M., and Osborne, B. A.: Dissolved carbon leaching from an Irish cropland soil is increased by reduced tillage and cover cropping, Agr. Ecosyst. Environ., 142, 393-402, https://doi.org/10.1016/j.agee.2011.06.011, 2011.

Weedon, G. P., Gomes, S., Viterbo, P., Österle, H., Adam, J. C., Bellouin, N., Boucher, O., and Best, M.: The Watch Forcing Data 1958-2001: a Meteorological Forcing Dataset for Land Surfaceand Hydrological-Models, WATCH Tech. Rep. 22, 41 pp., 2010. 